\title{
The Lower Vistula and Its Ice Problems
}

\author{
Wojciech Majewski \\ Institute of Hydroengineering, Polish Academy of Science, 7 Kościerska str. 80-328 Gdańsk, \\ e-mail:wmaj@ibwpan.gda.pl
}

(Received April 14, 2021; revised July 27, 2021)

\begin{abstract}
In many countries of the northern hemisphere during winter period ice forms appear on various water bodies, which results in significant changes of physical, chemical and ecological conditions. These changes are different in rivers, channels, lakes or once-through reservoirs. On the terrain of Poland ice always caused considerable problems affecting intensive inland navigation and other river use. These problems appeared especially on the Vistula River, which in 17th and 18th century was one of the most navigable rivers in Europe. The Vistula is the largest Polish river, which flows from the south in the Carpathian Mountains to the Baltic Sea in the north. It is the second largest river, after Neva, of the Baltic Sea catchment. The length of the Vistula is $1047 \mathrm{~km}$ and its catchment amounts to 194 thousand $\mathrm{km}^{2}$. The predominant part of the Vistula river basin (87\%) is now on Polish territory and the remaining (13\%) catchment is in Belarus, Ukraine and Slovakia. The course of the Vistula can be divided into three distinctly different sections: upper, middle and lower. These river sections have appropriate catchments with their tributaries. There are hydraulic structures on the main river course and on its tributaries which serve navigation, hydroenergy, flood protection, water supply and recreation. All over the Vistula catchment there are frequent floods during spring and summer time resulting from excessive precipitation but in winter caused by ice phenomena. Numerous flow problems appear especially along the lower Vistula course because of ice phenomena and they result very often in severe flood problems. The Vistula has a very variable time and spatial discharge, because of existing climate conditions over its catchment.

The aim of the paper is to present hydraulic and hydrologic characteristics of the Lower Vistula river with special emphasis on the management of this river section for navigation, hydroenergy, flood protection and water supply in view of ice phenomena appearing there. Information concerning changes of water characteristics due to various water temperatures are presented as well as on the formation of various forms of ice in flowing water. Numerous ice studies were carried out in Poland and especially on the Lower Vistula section as it was very ice prone and where many ice jams and ice-jam floods occurred. A special hydraulic situation existed at the mouth of the Vistula, which caused important floods in the 18th century and resulted in the construction of a special direct channel to the sea (Przekop Wisły) solving flood problems in this area. Information is presented on changes in open channel flow due to the appearance of ice cover and other ice forms. The paper includes ample information on the run,
\end{abstract}

(C) 2021 Institute of Hydro-Engineering of the Polish Academy of Sciences. This is an open access article licensed under the Creative Commons Attribution-NonCommercial-NoDerivs License (http://creativecommons.org/licenses/by-nc-nd/3.0/). 
consequences and studies connected with a very important ice-jam-flood on the upper part of Włocławek reservoir in 1982.

Key words: the Vistula river, the Vistula catchment, ice formation, ice problems in rivers, ice floods on the Vistula

\section{Notation}

All sympols are explained in the text when they appear for the first time

A $\quad-$ flow cross-sectional area $\left(\mathrm{m}^{2}\right)$,

$A_{I} \quad-$ flow cros-sectional area under the influence of ice cover $\left(\mathrm{m}^{2}\right)$,

$A_{B} \quad-$ flow cros-sectional area under the influence of river bottom $\left(\mathrm{m}^{2}\right)$,

$A_{0} \quad-\quad$ totalflow cros-sectional area under ice cover $\left(\mathrm{m}^{2}\right)$,

$a-$ coefficient in the logarithmic equation of velocity (Eq. 13),

$a=P_{I} / P_{B}-$ ratio of wetted perimeters of ice and river bottom (-),

$B \quad-$ width of the river channel (m),

$b-\quad$ coefficient in the logarithmic equation of velocity (Eq. 13),

$C_{C} \quad-$ latent heat of water crystalization $(340 \mathrm{~J} / \mathrm{kg})$,

$C_{W} \quad-$ specific heat of water $\left(4.18 \mathrm{~J} /\left(\mathrm{kg}^{\circ} \mathrm{C}\right)\right)$,

$d v / d y \quad-$ gradient of velocity over death,

$f \quad-$ resistance factor in Darcy-Weisbach equation (Eq. 7),

$f_{L} \quad-$ resistance factor for the underside of ice cover in Darcy-Weisbach equation,

$f_{B} \quad-\quad$ resistance factor for the river bottom in Darcy-Weisbach equation,

$\mathrm{Fr} \quad-$ Foude number (-),

$g \quad-$ acceleration due to gravity $\left(9.81 \mathrm{~m} / \mathrm{s}^{2}\right)$,

$H \quad-$ air humidity (\%),

$H \quad-$ elevation of energy line (Eq. 25) (m),

$H^{\prime} \quad-$ elevation of energy line (m),

$K \quad-$ conveyance,

$K \quad-$ correlation coefficient,

$k-\quad-$ coefficient of winter reduction of discharge (Eq.),

$K-\quad$ linear dimension of roughness (Eq. 12) (m),

$l \quad-$ thickness of ice cover $(\mathrm{m})$,

$l \quad-$ the length of mixing,

$n \quad-$ Manning roughness coefficient,

$n_{B} \quad-$ Manning roughness coefficient for river bottom,

$n_{I} \quad-$ Manning roughness coefficient for the underside of ice cover,

$n_{0} \quad-$ composite (equivalent) Manning roughness coefficient,

$P \quad-$ wetted perimeter $(\mathrm{m})$, 
- pressure $\left(\mathrm{Pa} / \mathrm{m}^{2}\right)$,

- wetted perimeter for the bed (m),

- wetted perimeter for ice cover $(\mathrm{m})$,

- total wetted perimeter $\left(P_{I}+P_{B}\right)(\mathrm{m})$,

- discharge $\left(\mathrm{m}^{3} / \mathrm{s}\right)$,

- hydraulic radius (m),

- hydraulic radius for river channel (m),

- hydraulic radius related to the underside of ice cover (m),

- hydraulic radius for the flow under ice cover (m),

- Reynolds number (-),

- slope of energy line, water surface (-),

- water temperature $\left({ }^{\circ} \mathrm{C}\right)$,

- air temperature $\left({ }^{\circ} \mathrm{C}\right)$,

- time (s),

- average flow velocity $(\mathrm{m} / \mathrm{s})$,

$v * \quad-$ dynamic velocity $(\mathrm{m} / \mathrm{s})$,

$V_{I} \quad-$ average velocity in the flow area under the influence of ice cover $(\mathrm{m} / \mathrm{s})$,

$v \quad-$ flow velocity $(\mathrm{m} / \mathrm{s})$,

$v_{\max } \quad-$ maximum velocity in the vertical $(\mathrm{m} / \mathrm{s})$,

$v_{\max / c} \quad-$ maximum velocity in the vertical, calculated $(\mathrm{m} / \mathrm{s})$,

$v_{\max / m} \quad-$ maximum velocity mesured $(\mathrm{m} / \mathrm{s})$,

$W \quad-$ wind speed $(\mathrm{m} / \mathrm{s})$,

$x, y \quad-$ coordinates in flow cross-section (m),

$y \quad-$ water depth (m),

$y_{\max } \quad-$ water depths of the location of maximum velocity under ice cover (m),

$y_{0} \quad-\quad$ distance from ice cover to zero velocity in logarithmic equation (m),

$y_{0} \quad-$ constant of integration (Eq. 11),

$\alpha_{I} \quad-$ coefficient of heat transfer in ice $\left(\mathrm{W} /\left(\mathrm{m}^{\circ} \mathrm{C}\right)\right)$,

$\beta \quad-$ empirical coefficient (Eq. 9),

$\varepsilon \quad-\operatorname{coefficient~(Eq.~4),~}$

$\eta \quad-$ coefficient (Eq. 4),

$\kappa-$ Karman constant,

$\rho_{W} \quad-\quad$ water density $\left(\mathrm{kg} / \mathrm{m}^{3}\right)$,

$\rho_{I} \quad-$ ice density $\left(\mathrm{kg} / \mathrm{m}^{3}\right)$,

$\phi \quad-$ heat flux density $\left(\mathrm{W} / \mathrm{m}^{2}\right)$,

$\phi_{R} \quad-\quad$ heat flux density due to solar radiation $\left(\mathrm{W} / \mathrm{m}^{2}\right)$,

$\phi_{B} \quad-$ heat flux density due to long wave radiation $\left(\mathrm{W} / \mathrm{m}^{2}\right)$,

$\phi_{E} \quad-$ heat flux density due to evaporation $\left(\mathrm{W} / \mathrm{m}^{2}\right)$,

$\phi_{H} \quad-$ heat flux density due to convection $\left(\mathrm{W} / \mathrm{m}^{2}\right)$, 
$\begin{array}{ll}\phi_{p} & - \text { heat flux density due to precipitation }\left(\mathrm{W} / \mathrm{m}^{2}\right), \\ \phi_{B / W} & - \text { heat flux density from river bottom to water }\left(\mathrm{W} / \mathrm{m}^{2}\right), \\ \phi_{W / I} & - \text { heat flux density from water to ice }\left(\mathrm{W} / \mathrm{m}^{2}\right) .\end{array}$

\section{Introduction}

On inland waterways of many countries of the northern hemisphere during winter period various ice forms appear on the water bodies, which results in significant changes of flow regime as well as physical, chemical and ecological conditions of the lakes, rivers, channels or once-through-reservoirs. One of such rivers is the Vistula, the largest Polish river and the longest river of the Baltic Sea catchment. The Vistula flow direction is from south to north, which results in many winter floods. As concerns discharge it is the second largest after Neva (Russia). The length of the Vistula is 1047 $\mathrm{km}$ and its catchment amounts to 194 thousand $\mathrm{km}^{2}$. Predominant part of the Vistula river basin -169 thousand $\mathrm{km}^{2}(87 \%)$ is now on the Polish territory and the remaining $(13 \%)$ catchment is in Belarus, Ukraine and Slovakia. The Vistula catchment in Poland occupies $54 \%$ of its territory. The course of the main Vistula channel is totally on the terrain of Poland and can be divided into three distinctly different sections: upper, middle and lower (Fig. 1). These river sections have appropriate catchments with their tributaries. The average multiannual discharge of the Vistula at its mouth is $1060 \mathrm{~m} 3 / \mathrm{s}$. Maximum recorded discharge after Second World War was $7840 \mathrm{~m}^{3} / \mathrm{s}$ and minimum $253 \mathrm{~m}^{3} / \mathrm{s}$. The Vistula discharges $7 \%$ of all fresh water to the Baltic Sea. The source of the Vistula is in Carpathian Mountains at the elevation of $1060 \mathrm{~m}$ above sea level. The highest average multiyear discharges appear in March and April, while the lowest in December. The average annual outflow of the Vistula to the sea is $34.1 \mathrm{~km}^{3}$, maximum (wet year) $51.7 \mathrm{~km}^{3}$, and minimum (dry year) $20.5 \mathrm{~km}^{3}$. There are many hydraulic structures on the main river channel and on its tributaries, which serve hydroenergy, navigation, water supply, flood protection and drought mitigation.

From the dawn of Polish history, the Vistula was one of the driving forces of the country's economy. It also played an important cultural role and frequently also a defensive one. Throughout the 17th century and during the 18th century, it was the most navigable river in Europe. It served as a waterway between Poland and the port of Gdańsk, which was our gateway to the outer world. Through this river channel, over a quarter of a million tons of raw materials and agricultural goods were shipped yearly, despite primitive means of transportation. Because of the partitions of Poland at the end of 18th century, the Vistula lost its former importance, becoming more and more neglected, as the occupying powers treated the river and its basin as peripheral to their economy. Other European waterways, such as the Rhine, the Rhone, the Seine or the Danube, improved their navigability to a very high level. At the same time, these rivers generated electric energy - indispensable for economic growth. They served also as a water supply for people, agriculture, and industry. 


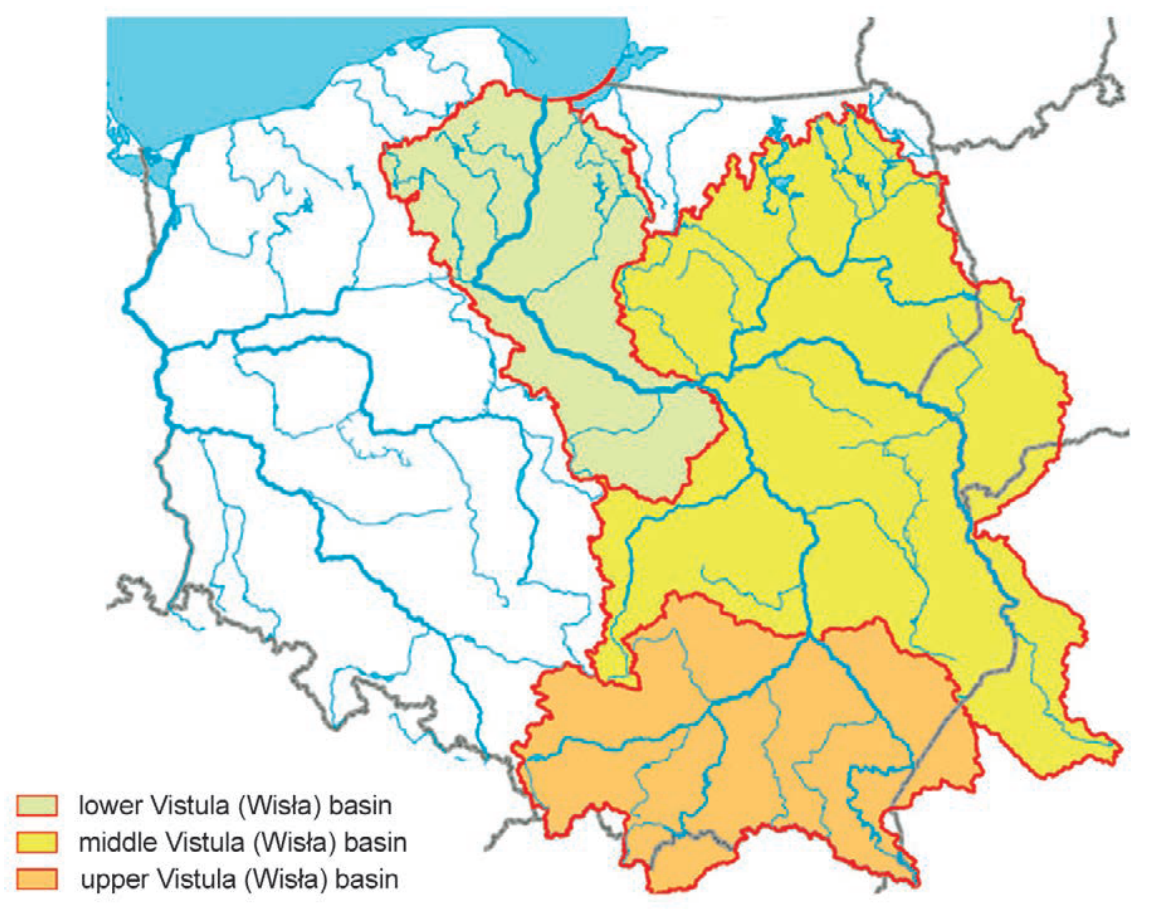

Fig. 1. The catchment of the Vistula River and its subcatchments

After World War II, when the contemporary boundaries of Poland were established, the Vistula became an important river in the center of our state. This location resulted in using of the river's economic capacity.

Program, entitled the Cascade of the Lower Vistula River was proposed after the War (Lover 1993), which included the construction of eight barrages with run-of-river reservoirs. Lower Vistula presents about 50\% of the total technical hydroenergy potential of Poland. Within the framework of this project, the first barrage - Włocławek was put into operation in 1970. The construction plans for the next barrages - Ciechocinek, downstream of Włocławek, and Wyszogród upstream were at an advanced stage. The construction site for the barrage Ciechocinek was in preparation. Main emphasis of this project was directed to the navigation and power generation. Furthermore, it was emphasized that the whole Vistula River causes flood dangers, which over its lower reaches were mainly due to ice jams.

The Lower Vistula is the final river section (390 km long) and was, and still is very prone to the formation of various ice phenomena (Majewski et al 1985). Most of the floods, which appeared along this section, were caused by ice jams. Therefore it is very important to have good knowledge of the appearance of various ice phenomena (frazil ice, boarder ice, bottom ice, ice floes, frazil pans), and the formation of solid ice cover when whole river width is covered with ice. Important fact is the time of the formation of ice phenomena but also ice break-up date. This situation is complicated 
by the fact that ice break-up on the Vistula course in the south of Poland is about 10 days earlier than in the north and it is important to prepare passage of ice to the sea through the frozen downstream Vistula section. This is usually accomplished by the use of ice-breakers, which form the ice free channel in totally ice covered river. There are many factors, which determine the flow of broken ice downstream along the final Vistula section. These are: river discharge, wind speed and direction, and water level in the sea. Further complication along the Lower Vistula is caused by variable hydrometeorological conditions. They cause that during one winter season it is possible to have one ice period, while in the other two or even three ice periods. By means of ice period we understand situation from ice formation with solid ice cover till ice break-up and ice run.

\section{Studies of Ice Problems in Poland}

Ice phenomena presented always on the Polish terrains significant problems especially on the rivers, which were extensively used for navigation. During the interwar period (1918-1939) there was first information concerning ice problems on rivers presented as Natural History of Ice (Dobrowolski 1923). These studies were mainly of engineering character and river exploitation.

After World War II there were important attempts to characterize ice problems on rivers by (Lambor 1971, Gołek 1957, and Pasławski 1970). These publications presented mainly practical problems i.e. how to take into account the influence of ice phenomena on the river flow regime as well as information on ice formation. Lambor (1948) in the Proceedings of Hydro-meteorological Service presented the genesis of the formation of frazil ice and in other Proceedings (Lambor 1959) he described ice problems, which appear on the inland waterways in Poland. In his text-book (Lambor 1971) Engineering Hydrology he presented one chapter on the winter flow in rivers. It was a very important source of practical knowledge for students and practicing engineers. Here he described the method of the coefficient of flow reduction due to ice phenomena. It indicated how much the free surface flow stage will increase when various ice phenomena will be present. It gave only the general knowledge about possible water level rise when river is covered with ice. His studies presented a lot of information of the knowledge on ice problems in rivers of Russia, which exist in severe winter climate. In text-book Applied Hydrology by Ozga-Zielińska, Brzeziński (1994) there is Chapter 4.4. Characteristics of Ice Phenomena, which presents general information about genesis and forms and ice phenomena carried out mainly by IMGW (Institute of Meteorology and Water Management). More information and studies about Ice problems was in the Central National Program PR7, Formulation and water management of water resources. Within this program there were special studies group devoted to Studies of ice phenomena on the rivers for the use of forecast and flood protection. Within Central Program of basic studies: Methods of analysis 
and utilization of water resources during 1985-1990 there was study group 04. Modeling of ice phenomena on rivers and one-through reservoirs. Within this study group two important publications appeared: Influence of ice cover on the hydraulic characteristics of of once-through-reservoirs on lowland rivers on the example of Wtoctawek Reservoir (Majewski 1987). This publication presented an extensive study on the ice jam flood on Włocławek reservoir including field measurements, theoretical analysis and calculation of back water profile with floating, stable ice cover. Special emphasis was directed to the evaluation of roughness coefficient of the underside of ice cover, which has a very important influence on the calculated water levels. Results of calculations show that it was possible to find out why during this complicated ice - hydraulic situation there was such high water level in the final section of Włocławek reservoir.

Grześ (1991) in publication Ice jams and Ice-jam Floods on the Lower Vistula, Mechanisms and Conditions presented an extensive account of ice-jam floods in previous centuries together with measurements of ice cover with hanging dams formed of frazil ice. All these measurements were carried out using simple methods, which were available during this time. First actions of icebreakers were described together with the limitations of their operation. This ample material indicates how all these ice phenomena were important for navigation, especially on the Lower Vistula.

These two comprehensive publications indicate that special influence on the ice studies in Poland had the flood on Włocławek reservoir in 1982. This flood with high economic and social losses showed that our knowledge concerning the forecast possibility of ice jam formation and ice-jam-flood is limited. Many information on ice engineering in open channels and hydraulic installations was presented in (Ice Engineering 1982, Majewski 1985 and Majewski 1986).

In doctor dissertation (Kolerski 2004) presented in the Institute of Hydroengineering of the Polish Academy of Sciences dealing with unsteady flow with ice cover in open channels and run-of-river reservoirs.

In important publication (Kolerski 2016), thesis for doctor habitilated presents mathematical modeling of ice phenomena on the inland waterways. This publication presents in detail mathematical equations necessary to formulate a model which will be able to reproduce ice phenomena on rivers. It presents the unsteady hydrodynamic equations of rivers considering the ice cover, thermal processes on water and ice surface. They are illustrated by several ice situations, which appeared on the Lover Vistula River.

Laboratory studies on ice formation and freeze-up in open channel flow were also carried out (Hammar et al 2002).

\section{Ice Jams and Floods along the Lover Vistula}

Detailed description of ice jams on the Lower Vistula, which was always very ice prone river, is very difficult because of incomplete information which remained till our times. Most detailed information are the marks of high water levels, which were 
installed on the walls of important buildings or defensive walls. There was always date and water level of such event. These marks indicate that most of the floods were in the beginning of spring during break-up and ice-run. Not all such marks remained till our times. The first flood marks are from the 15th century. More accurate information we have from the 19th century. They provided data concerning the time of flood, but also description of ice jam, its development and duration. Very important information was the discharge. In 19th century the outlet of Vistula to the sea (Bay of Gdansk) was very complicated as shown in Fig. 2. It is the copy of an old map. The shaded areas indicate flooded terrains during flood of 1829 and 1888.

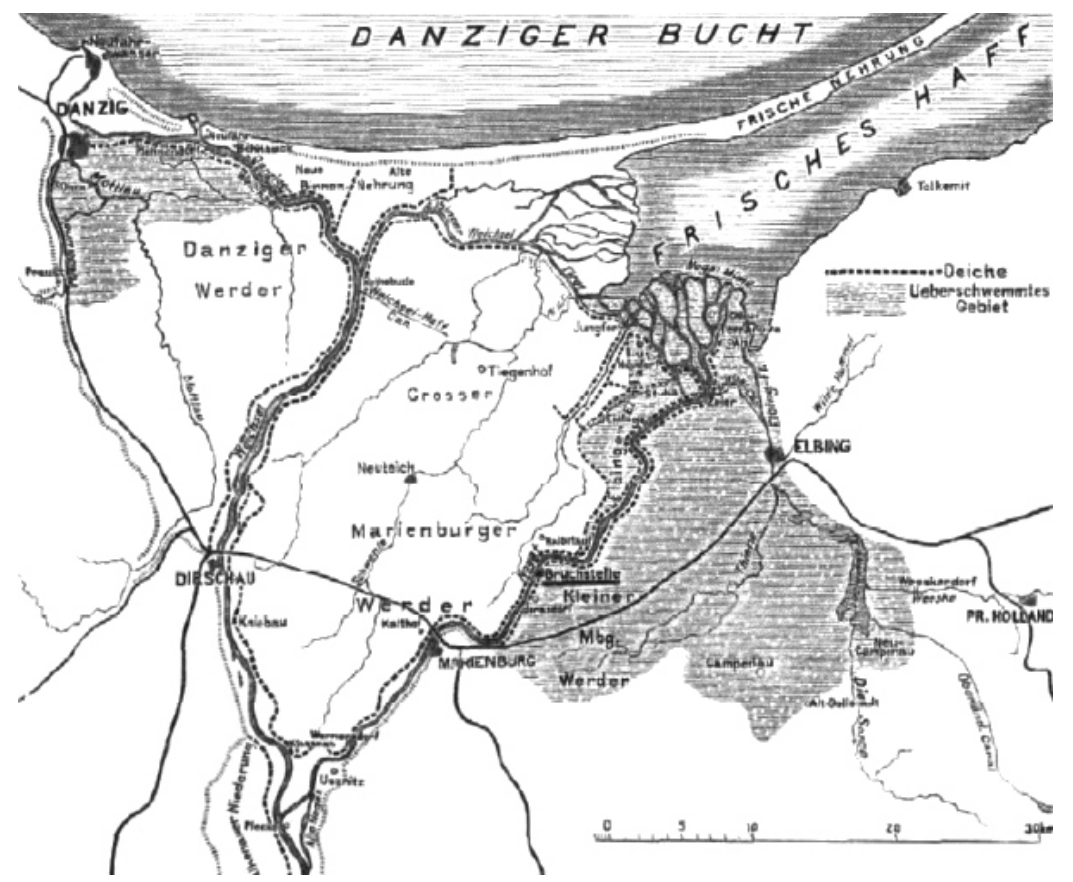

Fig. 2. The old map of Żuławy Wiślane with the complicated Vistula outlet to the Bay of Gdańsk

Żuławy Wiślane is the area which formed during centuries by sediment deposits, which were transported by the Vistula. This way a fertile horizontal terrain was formed used for agriculture. It amounts to $1700 \mathrm{~km}^{2}$, while about $450 \mathrm{~km}^{2}$ are depressions. At present Żuławy can be divided into 3 distinctive parts. Gdańsk Żuławy located on the west side of the main Vistula channel. Large Żuławy or Malbork Żuławy, which are located between the main Vistula channel and the Nogat river leading to the Wiślany Gulf, and the Elbląg Żuławy, which occupy terrain to the east of Nogat channel.

In the 18th century the Vistula outlet to the sea was very different than it is now. The Vistula flowing to the north at the location of Biała Góra branched with the outflow Nogat to the Gulf of Vistula (Zalew Wiślany). Farther north the Vistula divided 
into the Gdańsk Vistula (Wisła Gdańska) flowing to the west and Elbląg Vistula (Szkarpawa) flowing to the east. This complicated river system caused very often, during spring ice-run, jams and in consequence floods every three to four years. The main outlet of the Vistula to the Bay of Gdańsk was near the fortress Wisłoujście.

It is necessary to emphasize, that on the before mentioned Vistula channels there was no hydraulic structure, which could control the outflow of the Vistula to the sea. If an ice jam formed on the branch Nogat, the whole discharge was directed downstream to the Vistula branches (Gdańsk and Elbląg). In this situation it was difficult to create flood protection system, which would be effective in various hydraulic situations.

The engineering organizations postulated that this Vistula outlet system should be changed. There were discussions and proposals of such projects, however, they were complicated and very expensive. The most important floods in this area appeared in 1829, 1855, 1840, and 1888 (Majewski 2015).

Ice jam flood 1829 appeared after a very long, frosty and with large amounts of snow winter. The break-up appeared at the middle of April. Earlier break-up and ice-run started in the south of Poland. Ice cover on the Lower Vistula had the thickness of nearly $1 \mathrm{~m}$. Flood wave, coming from the south had the discharge of about 10 thousand cubic meters per second. The flood embraced Gdańsk Żuławy. Left hand flood levies of the Vistula were breached in many places and the flood wave was proceeding towards Gdańsk. A huge ice jam formed near the outlet of Vistula to the Bay of Gdańsk near the fortress of Wisłoujście. This caused high increase of water level. The city of Gdańsk was flooded in some places nearly to the first floor. This situation caused that main flow of the Vistula turned to the west in the direction of Brzeźno, where it formed new outlet to the sea. This way the new harbor of Gdańsk was created and the famous Westerplatte. During this flood about $340 \mathrm{~km}^{2}$ were flooded and about 10 thousand inhabitants of Żuławy became homeless. There were also considerable economic losses.

Ice-jam flood 1855 enclosed the whole lowland area of Pomorska Vistula (Żuławy Wielkie). Winter was very frosty with large amounts of ice and snow. Spring began at the end of March. Ice cover thickness on the Lower Vistula reached $0.9 \mathrm{~m}$. The maximum discharge of the Vistula was estimated at $9900 \mathrm{~m}^{3} / \mathrm{s}$. About $600 \mathrm{~km}^{2}$ of Żuławy were flooded including all depression terrains. Flood resulted in large economic losses and death of about 100 people.

Ice-jam flood in 1840 appeared at the end of January on the Gdańsk Vistula at the location of Płonia because of large ice jam. It caused high water level, which breached the along-shore sand dunes and formed a new outlet to the Bay of Gdańsk. With time this outlet widened and was named Wisła Śmiała (Bold Vistula). This way the layout of the Vistula outlet was considerably changed. Part of the land which was now surrounded by various Vistula channels received the name of Wyspa Sobieszewska (Sobieszewska Island).

Ice-jam flood in $\mathbf{1 8 8 8}$ began because of the formation of ice-jam on the Nogat branch of the Vistula. This ice-jam and flood had very similar character as the events 
which appeared in 1829 and in 1855 . The winter this year was very long and full of ice and snow. Ice cover thickness on the Nogat branch reached 0.6 to $0.8 \mathrm{~m}$. Ice break-up in the south of Poland started earlier than in the north and high water discharge with broken ice met stable ice cover in the north. This way the main Vistula discharge was directed to the Nogat branch. Ice cover on this branch was broken and several local ice-jams formed, which resulted in breaching of right hand flood dykes and inundation of a very large area on the east terrain of Nogat. $400 \mathrm{~km}^{2}$ of arable land were flooded including all depression terrains. Huge economic losses resulted from this flood. These losses were compared with the cost of the proposed project to construct a new channel, $7 \mathrm{~km}$ long, leading directly to the Bay of Gdańsk. This was one of the crucial arguments for starting of this project.

Ice-Jam flood on Włocławek Reservoir in 1982. It was a very important flood with numerous economic losses. The run, damages and resulting changes of flood protection constructions are presented separately in point 17.

\section{Direct Vistula Channel to the Sea (Przekop Wisły)}

Numerous ice-jam floods which appeared in the 19th century at the outlet of the Vistula to the Baltic Sea caused significant economic and social losses. There were many proposals to solve this problem, however, they were very expensive. After the ice-jam flood in 1888 it was finally decided to start the project, which was proposed in 1877.

It consisted of constructing $7.1 \mathrm{~km}$ long and 250 to $400 \mathrm{~m}$ wide direct channel from the place Przegalina to the sea. It was also designed to carry out training of the section of the Vistula from its outlet to the Silno ( $\mathrm{km} \mathrm{718)} \mathrm{by} \mathrm{means} \mathrm{of} \mathrm{groins} \mathrm{to}$ form navigable waterway from Gdańsk to the waterways of Germany. This way the lengths of the Vistula was shortened by about $10 \mathrm{~km}$ and it was necessary to close the connections of the main Vistula river channel with the branches Nogat, Gdańsk Vistula and Szkarpawa by means of navigation locks and flood gates (Majewski 2015).

The new channel was equipped with flood dykes on both sides. In 1891 the whole technical documentation of the channel was ready and the works started. It was decided that the whole cross-sectional profile of the channel will have flood dykes on both sides of the channel. It was a gigantic engineering project and the official opening of the channel was planned for 31 March 1895. The channel occupied 700 ha of agricultural land together with numerous farms. The time for the execution of the project was very short -5 years. The new layout (existing at present) of the Vistula channels is shown in Fig. 3.

\section{Characteristics of the Lower Vistula}

The section of Lower Vistula is highly variable from hydro-morphological point of view. It is possible to distinguish four different sections of the Lower Vistula going from the upstream point (Fig. 4). 


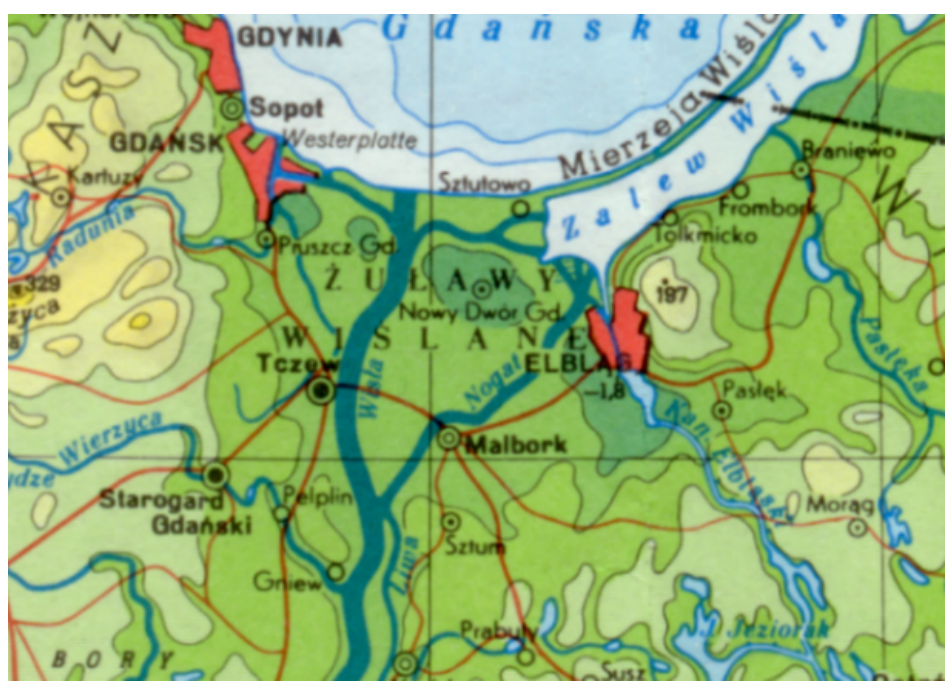

Fig. 3. Present layout of the Vistula outlet to the sea

- From the confluence of the Narew River to the upstream part of Włocławek reservoir. This section is very close to natural river with lots of shoals, islands and braided channels.

- Włocławek reservoir (commissioned in 1970), which was formed by the barrage damming the Vistula River. The reservoir is run-of-river type and is about $60 \mathrm{~km}$ long.

- Downstream from the barrage Włocławek to the place Silno the Vistula River is degraded by the operation of the barrage Włocławek and hydraulic power plant.

- From the place Silno to the Bay of Gdańsk (Baltic Sea) the Vistula was trained for navigation purposes in the 19th century. This section has flood dykes on both sides of the river protecting against discharge of $1 \%$ probability.

Differentiated character of the Lower Vistula results in different time and character of the formation of ice phenomena and permanent ice cover. In 1829 a very severe ice jam close to the mouth of Vistula resulted in flooding of Gdańsk. In 1840 another ice jam caused the breach of coastal dunes and formation of new outlet of Vistula to the sea. Formation of ice-jams, especially along final section (30 km long) lead to substantial changes in the river mouth which was developed in 1895 in the form of direct channel to the sea.

In 1982 there was a very important flood in the region of upper part of Włocławek reservoir caused by exceptional hydraulic and meteorological conditions, which resulted in large ice jam. The main reason of this flood was the formation of considerable amount of frazil ice on the river upstream from the reservoir and inflow of this ice to the reservoir, where permanent ice cover already existed. Frazil ice caused hanging dams and considerable decrease of flow cross-sections, which resulted in very high 


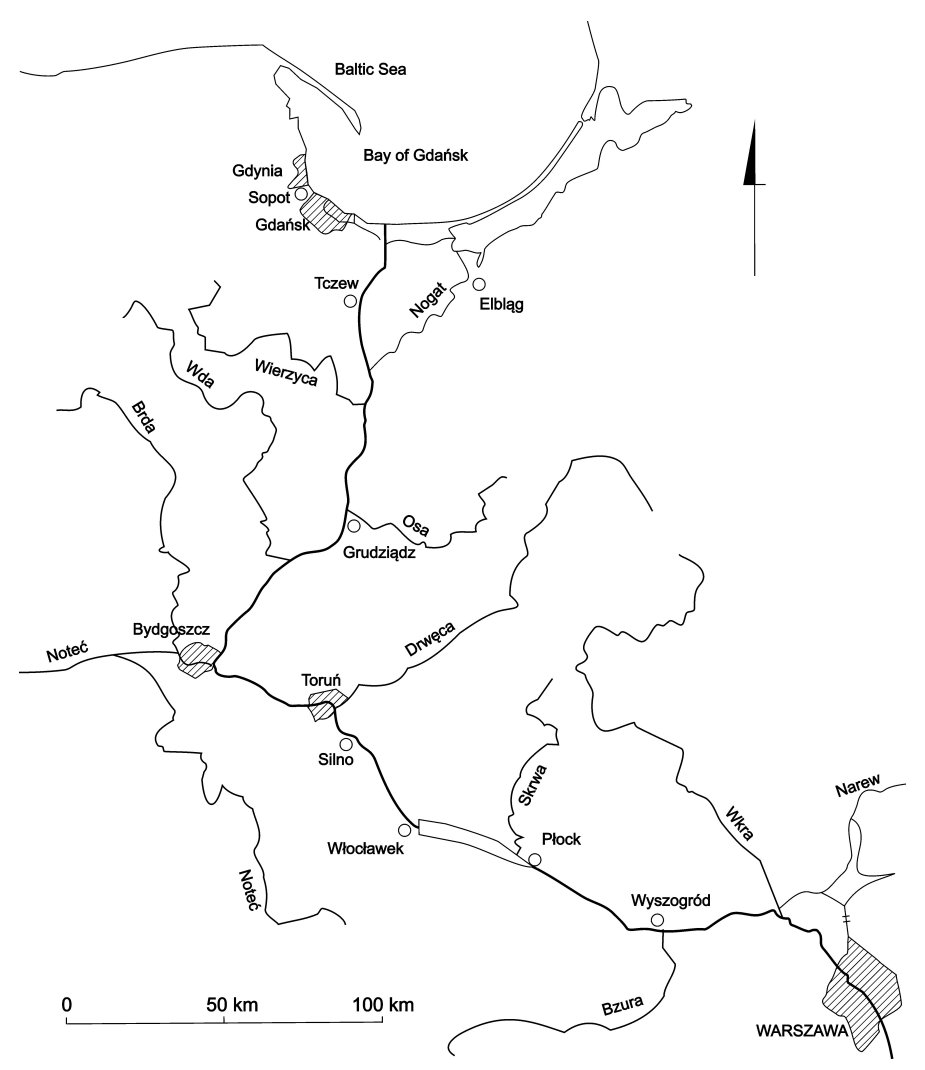

Fig. 4. The Layout of the Lower Vistula

water stages. They exceeded the crest of side dams, overtopping them and breaching. Large areas of the city Płock and agricultural land were flooded.

\section{Ice Phenomena along the Lower Vistula}

Lower Vistula is $390 \mathrm{~km}$ long and extremely differentiated. Frazil ice is very common especially upstream from Włocławek reservoir. On the Włocławek reservoir due to lower flow velocities permanent ice cover forms earlier than on the other river sections. The thickness of ice very often exceeds $0.5 \mathrm{~m}$. Frazil ice presents special problems on the reservoir, when permanent ice cover forms and upstream from the reservoir there is free water surface where large amounts of frazil ice develop and flow into the reservoir forming hanging dams and increase of water level even during low water discharge. Construction of Włocławek barrage and reservoir resulted in ice jam problems, which appeared during ice formation and later during ice break-up (Fig. 5). Comparison of ice phenomena on the river and nearby lakes shows that when ice forms on the lake it stays there till spring when higher temperatures cause melting of ice. On Vistula River changes of the state of ice cover depend very much on dynamic conditions caused by 
the changes of discharge. Winter 1981/82 was one of the most severe seasons of the last years. The whole Lower Vistula was covered with thick solid ice, which in some places exceeded $0.5 \mathrm{~m}$ (Fig. 6). Development of ice cover on the Lower Vistula usually begins on Włocławek Reservoir, where flow velocities are smaller than on the river upstream or downstream form the reservoir.

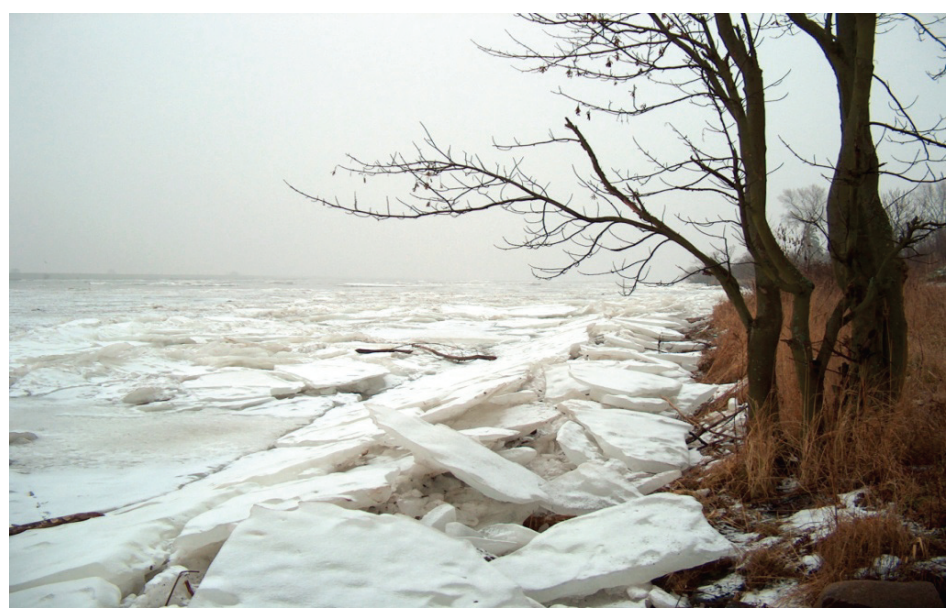

Fig. 5. Ice cover on the final section of the Lower Vistula

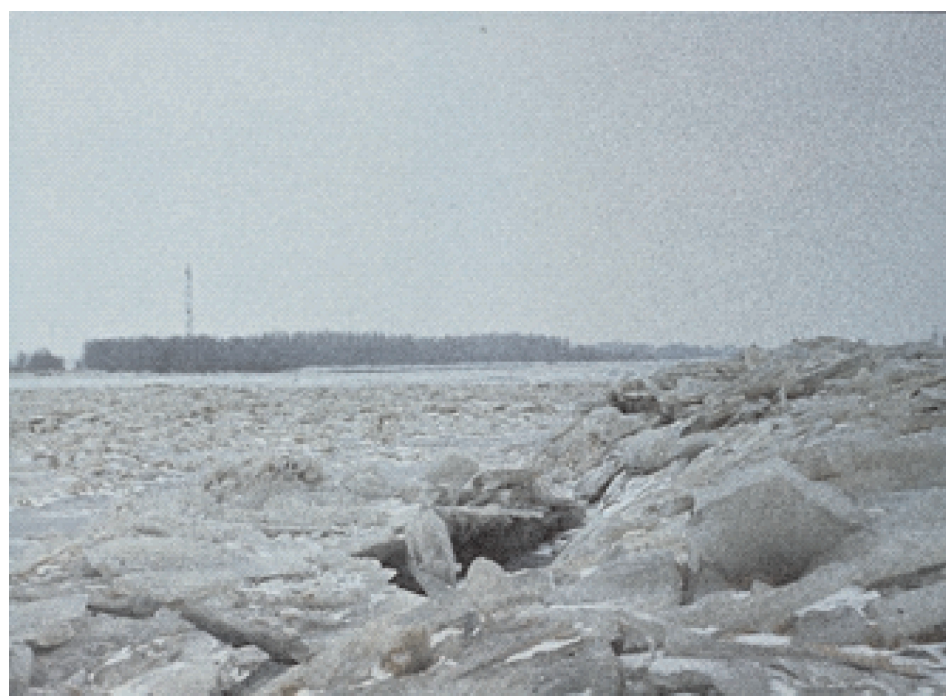

Fig. 6. Ice cover on the upper part of the Włocławek reservoir in winter 1982

This results in the stoppage of frazil ice, which subsequently freezes and forms permanent ice cover. This prevents further formation of frazil ice along this river section. Downstream from the reservoir there is always ice free river section. Further 
downstream ice cover forms gradually from border ice. Discharge of ice floes in the downstream direction in spring requires always assistance of ice-breakers.

Observations of the ice phenomena were carried nearly regularly since the second half of 19th century. They concerned the appearance of any ice forms on the Vistula in the vicinity of Torun and also situations when the whole river width was covered with permanent ice (Majewski 2007). Multiyear changes of the duration (amount of days) of ice phenomena and permanent ice cover for the Lower Vistula in cross-section Torun in the form of 10-year consecutive movable average are shown in Fig. 7.

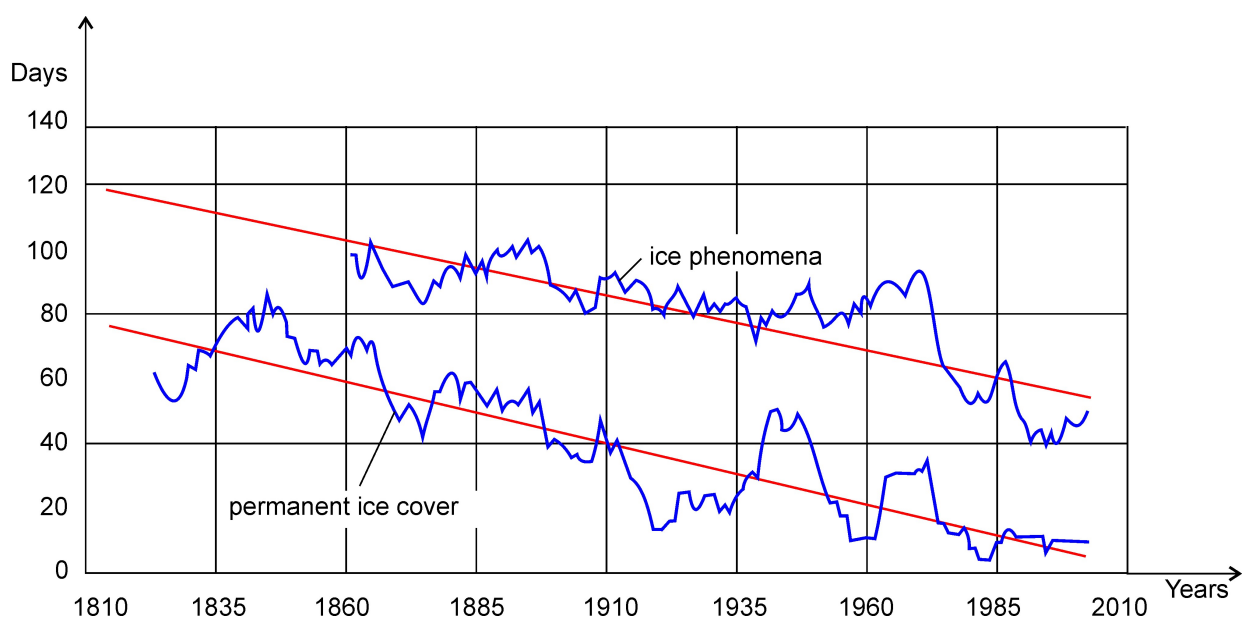

Fig. 7. Duration of ice phenomena and permanent ice cover on the Vistula in Toruń

Data show that in the second half of 19th century ice phenomena along the Lower Vistula appeared during about 100 days, while at the beginning of 21 st century this amount decreased to about 50 days. Number of days, during the same period of time, with permanent ice cover decreased from about 70 nearly to zero. Both trends have similar character. They indicate systematic decrease of the amount of days with ice phenomena and permanent ice cover. This may present the influence of climate warming. Despite these long term indications we are also faced with more frequent appearance of extremes in the form of very mild winters, but also severe ones.

\section{Basic Physical Parameters Connected with the Formation of Ice}

The basic physical parameters of water and ice, which play dominant role during the appearance of ice phenomena are: water and ice density, specific heat of water and ice, latent heat of crystallization/fusion, and heat transfer coefficient of ice (Majewski 2009).

Density of water $\left(\rho_{w}\right)$ has a very unique characteristics with changing temperature. Considering problems of ice formation we will be mainly interested in changes of water density in the range of temperatures from $+8^{\circ}$ Celsius to $0^{\circ} \mathrm{C}$. 
The maximum water density at $4^{\circ} \mathrm{C}$ is $1000 \mathrm{~kg} / \mathrm{m}^{3}$ (Fig. 8). During the increase or drop of temperature from $4^{\circ} \mathrm{C}$ the water density is decreasing. It can be calculated from Eq. 1

$$
\rho_{w}=1000-\frac{(t-4)^{2}(t+283)}{503.57(t+67.2)}
$$

where:

$$
\begin{aligned}
& t-\text { water temperature }\left({ }^{\circ} \mathrm{C}\right), \\
& \rho_{w}-\quad \text { water density }\left(\mathrm{kg} / \mathrm{m}^{3}\right) .
\end{aligned}
$$

Changes of water density are shown in Fig. 8.

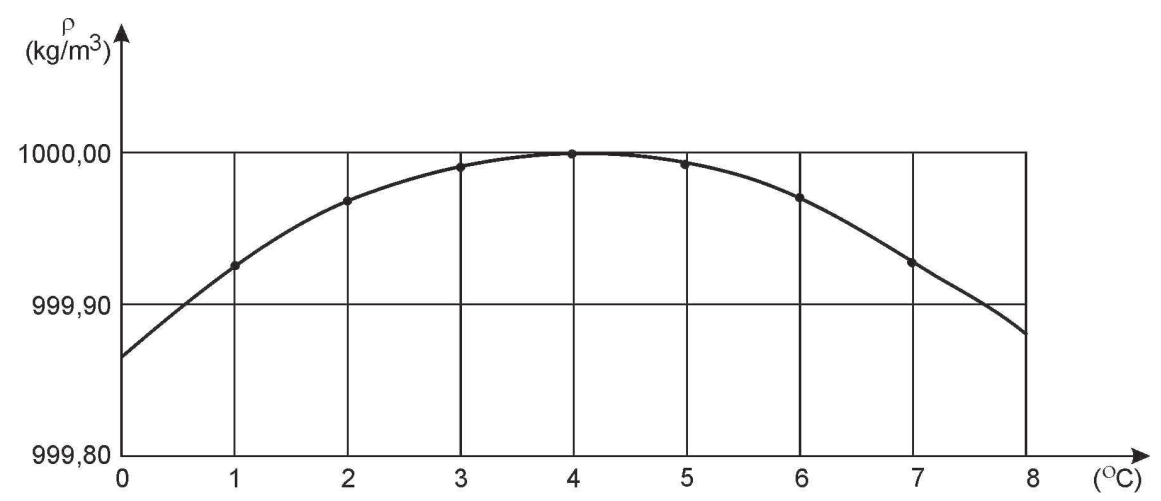

Fig. 8. Water density in the range of temperatures from $0^{\circ}$ to $8^{\circ}$

Table 1. Values of water density in the range from $0^{\circ}$ to $8^{\circ}$

\begin{tabular}{|c|c|}
\hline$T_{W}\left({ }^{\circ} \mathrm{C}\right)$ & $\rho_{w}\left(\mathrm{~kg} / \mathrm{m}^{3}\right)$ \\
\hline 8 & 999.88 \\
\hline 7 & 999.93 \\
\hline 6 & 999.97 \\
\hline 5 & 999.99 \\
\hline 4 & 1000.00 \\
\hline 3 & 999.99 \\
\hline 2 & 999.97 \\
\hline 1 & 999.93 \\
\hline 0 & 999.87 \\
\hline
\end{tabular}

In water bodies with flowing water - rivers, channels, water temperature is always nearly uniform from the surface to the bottom due to turbulence. Thus water particles of $0^{\circ} \mathrm{C}$ may appear over the whole depth and thus creating conditions for ice formation. In natural conditions the phenomenon of water supercooling very often appears. This 
supercooling may reach even $-2^{\circ} \mathrm{C}$. This way in turbulent flowing water various forms of ice may form over the whole depth of flow.

Specific heat of water $\left(c_{P}\right)$ is the amount of heat energy which is necessary to change $1 \mathrm{~kg}$ of water by $1^{\circ} \mathrm{C}$. It amounts on the average $4.18 \mathrm{~kJ} /(\mathrm{kg} \mathrm{K})$. This value has small changes with temperature, but also because some admixes. Water temperatures in natural conditions change due to the heat flux to or from the water body, mainly at the water surface.

Latent heat of fusion/crystallization $\left(c_{C}\right)$ is the amount of heat which is realized from the water body when it is turned into ice. This amount of heat must be transferred to the atmosphere when water turns into ice and therefore this process is considerably delayed and process of ice freezing takes longer time. Similar but reverse process takes place during ice melting. Here considerable amount of heat energy must be supplied to cover latent heat of fussion. This process is presented in Fig. 9.

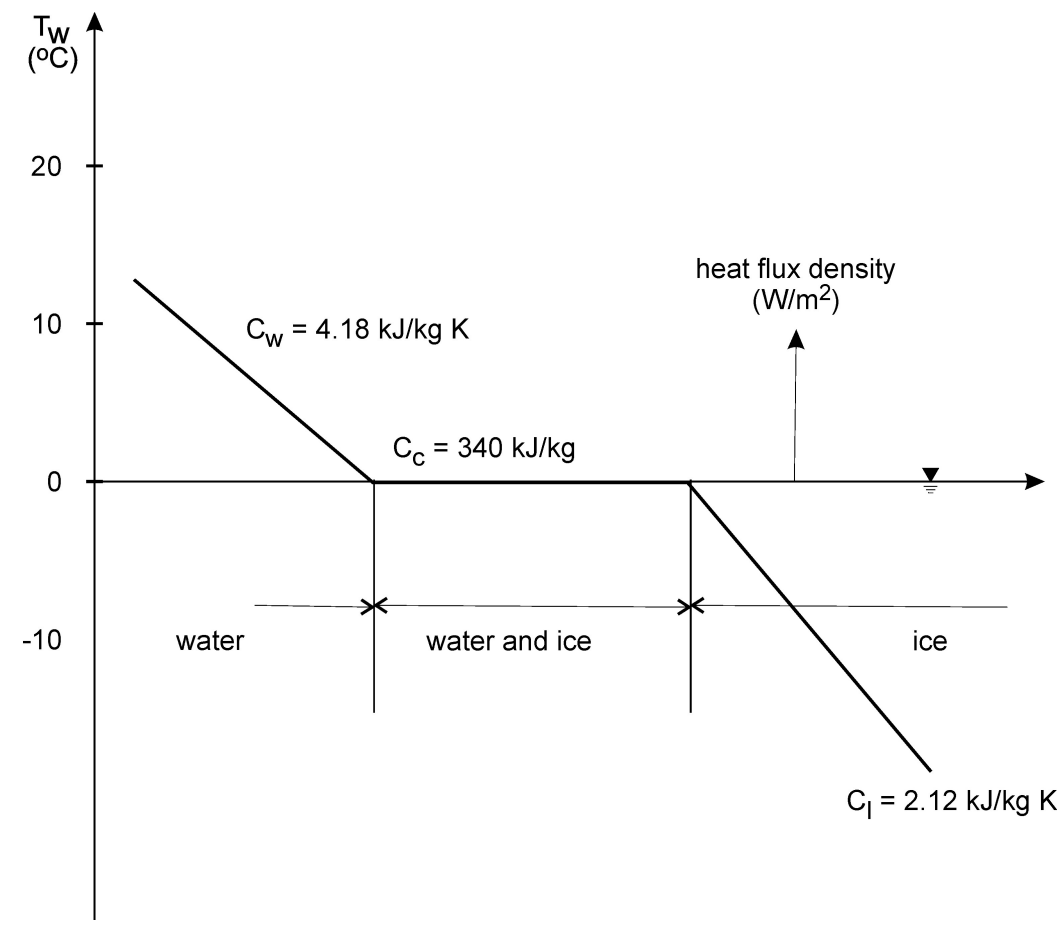

Fig. 9. Scheme of ice formation

Specific heat of ice $\left(c_{I}\right)$ is different than specific heat of water. Specific heat of ice is $2.12 \mathrm{~kJ} /(\mathrm{kg} \mathrm{K})$. This value is for pure crystalline ice. It may be different for various kinds of ice. This value is small in comparison to the latent heat of crystallization/fusion of ice. Therefore the process of water crystallization or fusion of ice has important influence on thermal regime of inland waters. 
Ice density $\left(\rho_{I}\right)$ of pure crystalline ice is $916 \mathrm{~kg} / \mathrm{m}^{3}$ and this results in floating of ice on the water surface. This indicates also that ice after freezing has larger volume than water. We can observe this in breaking a glass bottle full of water after freezing. Ice can have various crystalline structure, which can have even smaller density than pure crystalline ice. The snow ice, which can include air in its volume (sponge structure) can have much smaller density than crystalline ice. This results in high possibility of such ice to float to water surface. During the formation of frazil ice in flowing waters we observe the attachment of ice to various plants growing on the bottom or even stones lying on the bottom. The buoyancy of ice attached to various objects can cause its uplift to the water surface and transport over long distance. Very often we can observe plants or sediment particles attached on the underside of ice cover.

\section{Process of Ice Formation}

The process of ice formation is shown in Fig. 9. Due to the decrease of water temperature to the $0^{\circ} \mathrm{C}$ ice can start to form. However, there must be further loss of heat to overcome heat of crystallization $(340 \mathrm{~kJ} / \mathrm{kg})$. When farther heat loss to the atmosphere is present increase of ice volume takes place. Specific heat of ice (solid body) is different than water $\left(2.12 \mathrm{~kJ} /\left(\mathrm{kg}{ }^{\circ} \mathrm{C}\right)\right.$.

Heat transfer coefficient of ice $\left(\alpha_{I}\right)$ has the value of $2.2-2.3 \mathrm{~W} /\left(\mathrm{m}{ }^{\circ} \mathrm{C}\right)$. This value depends on the internal structure of ice. Ice behaves as every solid body. The value of heat transfer coefficient of ice is rather low and therefore ice cover forms good insulation of water body against loosing heat (Tsang 1982).

\section{Ice Formation on Stagnant Water Bodies}

On stagnant waters or water flowing with small velocity $(V<0.6 \mathrm{~m} / \mathrm{s})$, due to heat transfer to the atmosphere inverse stratification forms, which means that cold water, close to $0 \mathrm{oC}$, is on the surface and warmer water is below. When latent heat of crystallization is overcome water starts to change to ice, and its thickness is gradually increasing on the underside of ice cover in relation to the amount of heat flux to the atmosphere.

Ice formation is a slow process caused by the transfer of latent heat of crystallization, which is much higher than specific heat of water. This process may be retarded by the undulation or surface currents caused by wind resulting in some turbulence in water surface. The increase of ice cover thickness is gradually slowed down because ice creates good insulation for water below ice cover. Moreover, the heat flux from the bottom, which was negligible for free surface flow, now cannot be neglected. It results in the small increase of water temperature below ice cover and thus prevents any ice formation in this water volume. Ice cover which formed in autumn on stagnant water usually stays till spring, when it thaws due to heat flux from the atmosphere. This process is shown in Fig. 9. 

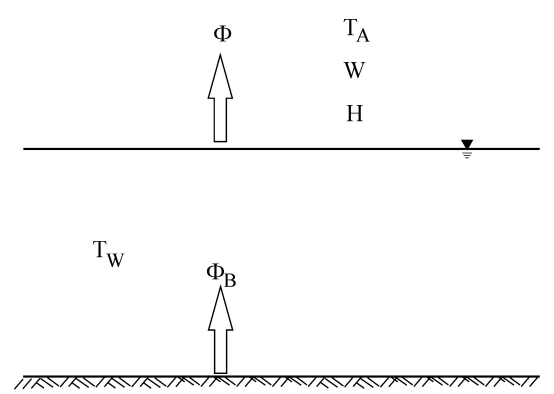
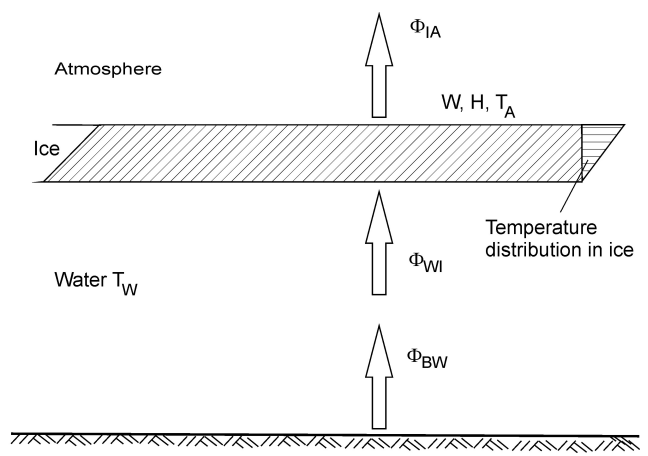

Fig. 10. Schemes for free water surface and water body covered with ice

Such process is called static on stagnant water or flowing with small velocity. The increase of ice thickness is on the underside. Some increase of ice thickness is possible on the upper ice surface by snow or hail. Thermal scheme of such situation is shown in Fig. 10. Heat flux density $\left(\Phi-\mathrm{W} / \mathrm{m}^{2}\right)$ from water surface to the atmosphere depends on the atmospheric conditions above water surface: air temperature $T_{A}$, wind speed $W$, air humidity $H$, state of clouds $(C)$, and water temperature. Heat flux from the river bottom $\left(\Phi_{B}\right)$ to water is small and can be neglected. This process can be written in the following form (Paily et al 1974):

$$
\Phi=\Phi_{R}+\Phi_{L}+\Phi_{B}-\Phi_{E}-\Phi_{H}-\Phi_{S}+\Phi_{B}
$$

All members of Eq. 2 have the dimension $\mathrm{W} / \mathrm{m}^{2}=\mathrm{J} /\left(\mathrm{s} \mathrm{m}^{2}\right)$ where:

$$
\begin{aligned}
& \Phi_{-}-\text {resultant heat flux density, } \\
& \Phi_{R}-\text { short wave solar radiation, } \\
& \Phi_{L}-\text { heat flux from long wave radiation, } \\
& \Phi_{E}-\text { heat flux due to evaporation, } \\
& \Phi_{H}-\text { heat flux due to convection and conduction, } \\
& \Phi_{S}-\text { heat loss caused by fall of snow or hail, } \\
& \Phi_{B}-\text { heat flux from river bottom. }
\end{aligned}
$$

Heat fluxes due to these physical processes can be determined by using various empirical formula. For the free surface situation heat fluxes due to snow fall and heat flux from river bottom are small in comparison to other heat fluxes and can be neglected. Thus Eq. 2 can be presented in the following form:

$$
\Phi=\Phi_{R}-\left(\Phi_{B}+\Phi_{L}+\Phi_{H}\right) .
$$

Predominant factors which influence heat flux density from water surface are: air temperature $\left(T_{A}\right)$, wind speed $(W)$, humidity $(H)$, and water temperature $\left(T_{W}\right)$. 
Very often heat flux density from water surface can be presented as the linear relation depending on water surface $\left(T_{W}\right)$ :

$$
\Phi=-(\varepsilon T W+\eta)
$$

where coefficients $(\varepsilon)$ and $(\eta)$ depend on mean values of air temperature, air humidity, and wind speed. For example for $T_{A}=-10^{\circ} \mathrm{C}, W=5 \mathrm{~m} / \mathrm{s}$, humidity $70 \%$ and water temperature in the range from 0 to $5^{\circ} \mathrm{C}$ the Eq. 3 will have the form:

$$
\Phi=-\left(36 T_{W}+239\right) \text {. }
$$

For other values of air temperature the magnitudes of heat flux density presents Fig. 11 . For water temperature $T_{W}=2^{\circ} \mathrm{C}$, air temperature $T_{A}=-5^{\circ} \mathrm{C}$, humidity $\mathrm{H}=$ $70 \%$, and wind speed $5 \mathrm{~m} / \mathrm{s}$ heat flux density $\Phi=190 \mathrm{~W} / \mathrm{m}^{2}$. For lower air temperature $T_{A}=-10^{\circ} \mathrm{C}$ heat flux density will be $\Phi=311 \mathrm{~W} / \mathrm{m}^{2}$.

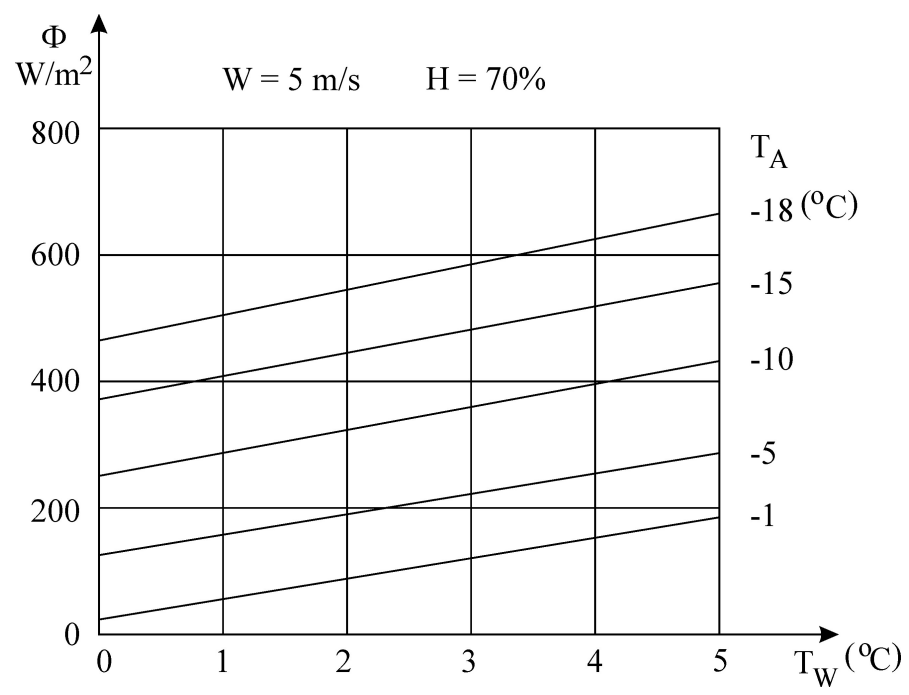

Fig. 11. Heat flux density $\left(\mathrm{W} / \mathrm{m}^{2}\right)$ from water surface for various water temperatures $\left(T_{W}\right)$ and various air temperatures $\left(T_{A}\right)$

The influence of wind on heat flux density from water surface to atmosphere is shown in Fig. 12. The change of wind speed from 0 to $5 \mathrm{~m} / \mathrm{s}$ for water temperature $+4^{\circ} \mathrm{C}$, air temperature $-5^{\circ} \mathrm{C}$, and humidity $70 \%$ shows quite visible increase of heat flux density of $160 \mathrm{~W} / \mathrm{m}^{2}$.

The volume of ice which forms in relation to water surface can be calculated using Eq. 6 when heat flux density is known

$$
V_{I}=\frac{\phi}{\rho_{I} C_{C}},
$$

where: 


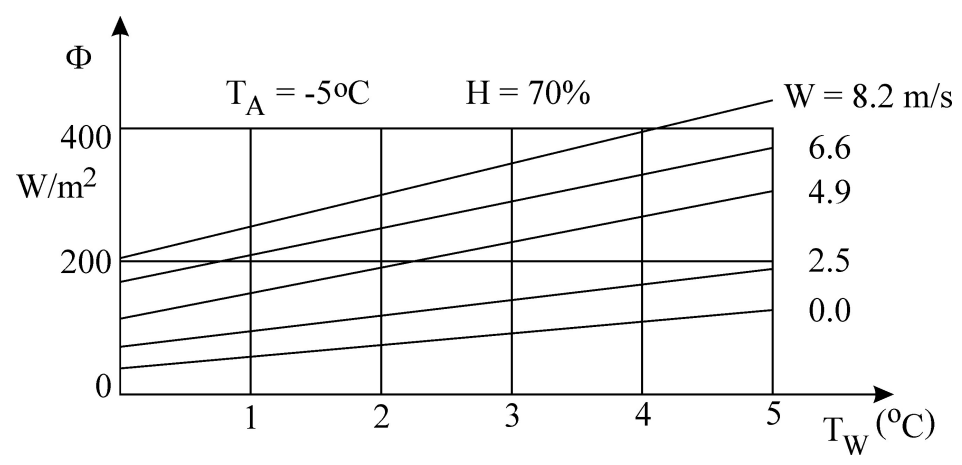

Fig. 12. Heat flux density $\left(\mathrm{W} / \mathrm{m}^{2}\right)$ from water surface for various water temperatures $\left(T_{W}\right)$ and various wind velocity $W(\mathrm{~m} / \mathrm{s})$

$$
\begin{aligned}
& V_{I}-\text { volume of ice }\left(\mathrm{m}^{3} /\left(\mathrm{m}^{2} \mathrm{~s}\right)\right) \\
& \Phi-\text { heat flux density }\left(\mathrm{W} / \mathrm{m}^{2}\right), \\
& \rho_{I}-\text { ice density }\left(916 \mathrm{~kg} / \mathrm{m}^{3}\right), \\
& C_{C}-\text { latent heat of ice crystallization }(340 \mathrm{~kJ} / \mathrm{kg}) .
\end{aligned}
$$

For water temperature $T_{A}=0^{\circ} \mathrm{C}$, air temperature $T_{W}=-15^{\circ} \mathrm{C}$, wind speed $W=5$ $\mathrm{m} / \mathrm{s}$, humidity $H=70 \%$, heat flux density will be $\Phi=370 \mathrm{~W} / \mathrm{m}^{2}$, and the calculated volume of ice $V_{I}=1.2 \cdot 10^{-6} \mathrm{~m}^{3} /\left(\mathrm{s} \mathrm{m}^{2}\right)$ will amount to about $0.1 \mathrm{~m}^{3}$ during one day over $1 \mathrm{~m}^{2}$. This means that ice cover of the thickness of about $I=0.1 \mathrm{~m}$ will form during one day.

\section{Increase of Ice Cover Thickness}

The formation of permanent stable ice cover changes not only hydraulic regime but also thermal regime of the water body. Ice cover is an isolating layer between water body and the atmosphere. The thermal scheme of a water body with ice cover is shown in Fig. 13. In this scheme we assume linear temperature distribution in the ice cover and constant heat transfer coefficient $\left(\alpha_{I}\right)$ over its whole thickness. We assume also that heat transfer from the river bed to water cannot be neglected. On the upper surface of ice cover the temperature is equal to the air temperature. On the underside of ice cover ice temperature is equal to the temperature of melting ice that is $0^{\circ} \mathrm{C}$. Ice cover always tends to achieve the state of equilibrium, which means that heat flux from ice surface to the atmosphere should be equal to the heat flux from the water body to ice cover. If ice thickness is too small, heat flux to the atmosphere will increase and automatically ice thickness will increase. These assumptions are not fully correct, because ice cover is not uniform over its whole thickness. If we can determine heat flux from ice surface to the atmosphere due to existing meteorological conditions we can calculate the thickness of ice cover assuming that water temperature and ice temperature at the underside of ice cover are identical and close to $0^{\circ} \mathrm{C}$, thus there is 
no heat transfer between water and ice. The increase of ice cover thickness is rather slow process. We can describe it by Eq. 7.

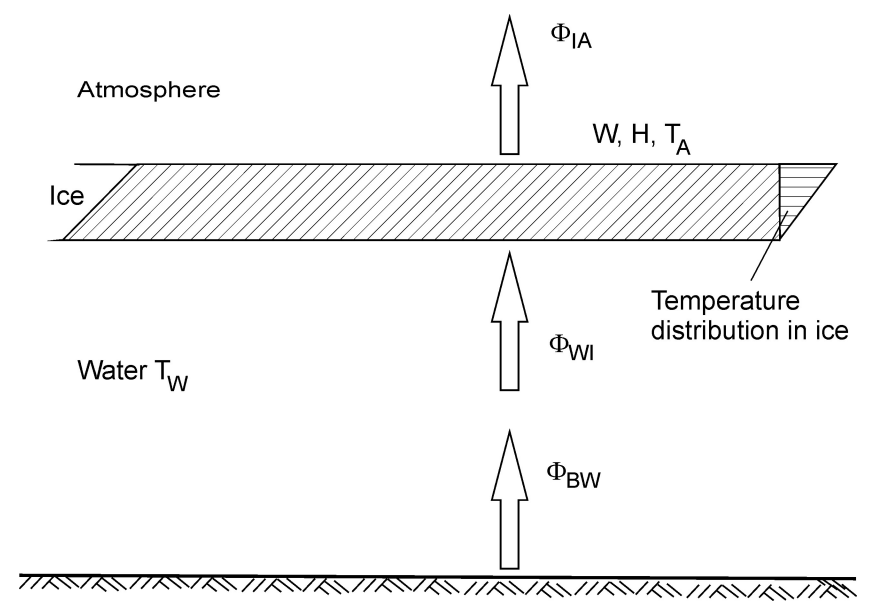

Fig. 13. Thermal scheme for the system atmosphere - ice - water - river bottom

$$
\Phi_{I A}=\rho_{I} C_{C} \frac{d I}{d t}=\alpha_{I} \frac{T_{A}-T_{W}}{I} .
$$

From the Eq. 7. after transformation we can obtain the changes of ice thickness with time in the following form

$$
I=\sqrt{\frac{2 \alpha_{I}}{\rho_{I} C_{C}}}\left(\int_{0}^{t}\left(T_{A}-T_{W}\right) d t\right)^{1 / 2} .
$$

This formula is difficult for practical application and therefore is often presented in the empirical form (Eq. 9)

$$
I=\beta \sqrt{N D D},
$$

where: $N D D$ is the sum of products of days with negative air temperatures, where $\beta$ - coefficient defined in the following way

$$
\beta=\sqrt{\frac{2 \alpha_{I}}{\rho_{I} C_{C}}} .
$$

If we will insert to the formula (10) the following data $\alpha_{I}=2.3 \mathrm{~W} /\left(\mathrm{m}^{\circ} \mathrm{C}\right), \rho_{I}=$ $916 \mathrm{~kg} / \mathrm{m}^{3}, C_{C}=340 \mathrm{~kJ} / \mathrm{kg}$ and will change seconds into days $(1$ day $=86400 \mathrm{~s})$, we will obtain the value of the coefficient $\beta=0.036 \mathrm{~m} /\left(\mathrm{d}^{\circ} \mathrm{C}\right)^{1 / 2}$. 


\section{Formation of Various Ice Forms on the Flowing Water}

Formation of ice on the flowing water is completely different from ice formation on stagnant waters or flowing with small velocity. This is a dynamic and not static process. Here we deal mainly with turbulent flow $\left(R e>R e_{C R}\right)$ and subcritical flow $(F r<1.0)$ (Chow 1959, Henderson 1966). This ice cover remains during whole winter till the moment of break-up and ice-run. Open channel flow has nearly uniform temperature distribution the cross-section, however, nonuniform velocity distribution in river cross-section. Various forms of ice, which appear in channel cross-section cause nonuniform velocity distribution. Ice in open channels can have the following forms (Shen 1991, Ashton 1986): border ice, bottom ice, frazil ice, ice pans, ice cover consisting of compressed ice pans or ice-slush fields. Permanent ice cover (over the whole water surface) changes radically flow conditions by changed velocity distribution and also thermal regime (Gerard 1980). Thermal regime of a water body is changed by the fact that permanent ice cover creates very good insulation of water from atmosphere and significantly decreases heat loss to the atmosphere. Heat flux from the river bottom, which in open channel flow was negligible, now starts to play visible role.

Solid (permanent) ice cover forms increased wetted perimeter and thus decrease of hydraulic radius (Griszanin 1969). Open channel flow can be regarded as flow with floating ice, which follows the water body. Ice cover in wide river channels is usually not firmly attached to the river shore. We can consider this type of flow as quasi pressure flow, where water depth is somewhat below the upper ice cover surface, and the flow cross-sction is diminished by the area of ice which is immersed in water.

\section{Border ice}

Border ice starts to form near the shores of river channels. In this area the flow velocities are usually smaller then in the middle of the channel, which may lead to water stratification and cooler water in the surface layer. Also the river banks cool down faster than water and this influences ice formation. Border ice increases towards the middle of the channel and finally may close the whole width of the channel. When discharge increases border ice breaks near the shore and assumes the form of floating ice. It may also break completely and move downstream. Border ice changes flow regime and also has strong influence on the ecological conditions along the shore. Border ice schematically and in natural conditions is shown in Fig. 14.

\section{Frazil and bottom ice}

Frazil ice is very popular and has the form of ice crystals of the size of few millimeters to one or two centimeters. It forms in the fast flowing water which may even be supercooled. Its view is presented on the mesh of the eyes of $5 \mathrm{~mm}$. It has a very dangerous, from technical point of view, feature that it easily attaches to practically everything. This way it may form bottom ice by the attachment to the bottom plants or 

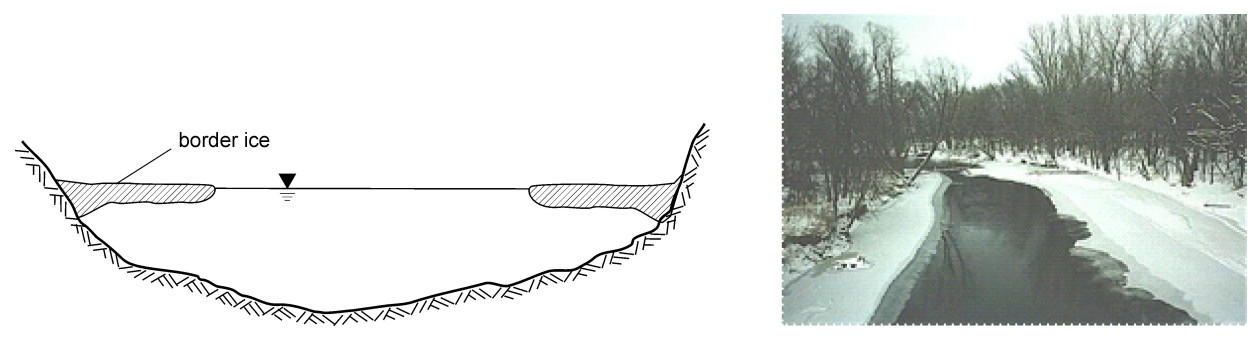

Fig. 14. Border ice. Hydraulic scheme and natural view

grains of sediment or stones. When these ice volumes increase they may be detached from the bottom and transported downstream. It may also completely block trash racks in front of turbines. Frazil ice and the scheme of bottom ice are presented in Fig. 15.

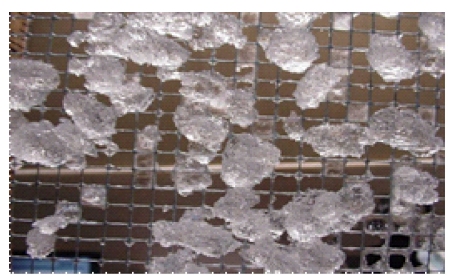

Frazil ice

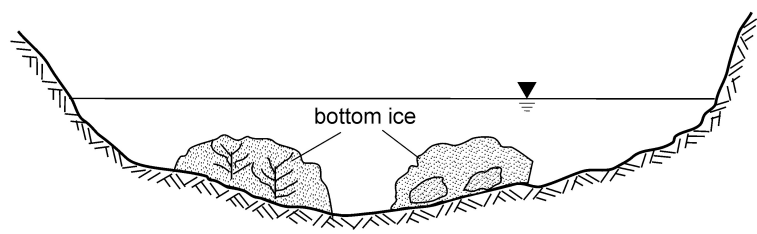

Bottom ice

Fig. 15. Frazil and bottom ice

\section{Ice pans}

Ice pans form on the water srface as the conglomerates of frazil ice. They have usually round shapes with higher rims. Very often there are large amounts of frazil ice on the underside of ice pans (Fig. 16). They move downstream with the current. When they meet an obstacle they stop and create permanent ice cover of a very rough surface and also very rough underside. This creates significant roughness and flow resistance. Ice over on the Vistula in Płock is shown in Fig. 17.

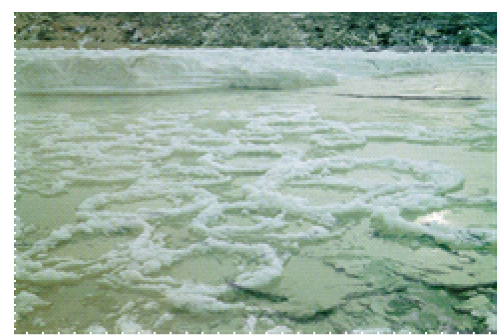

Ice pans on water surface

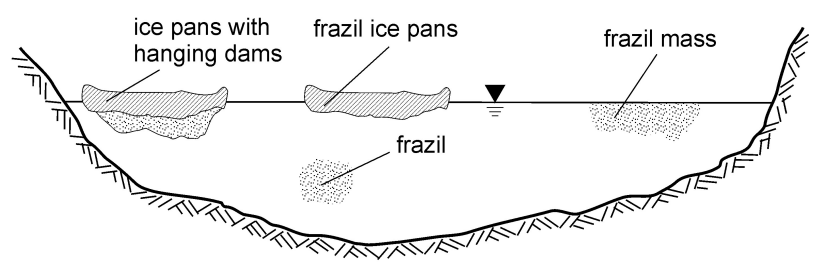

Ice pans in river cross-section

Fig. 16. Ice pans on the river 


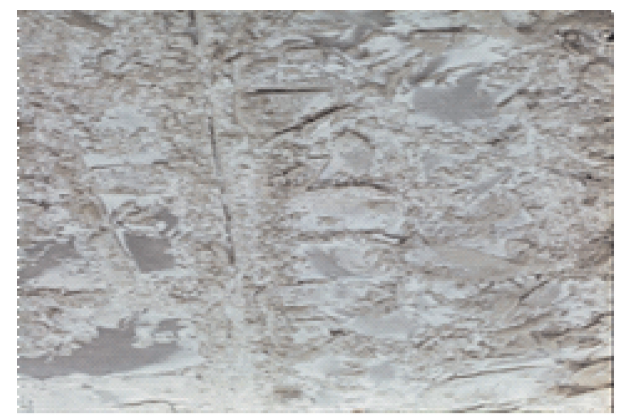

Ice cover on the Vistula formed with compressed ice pans

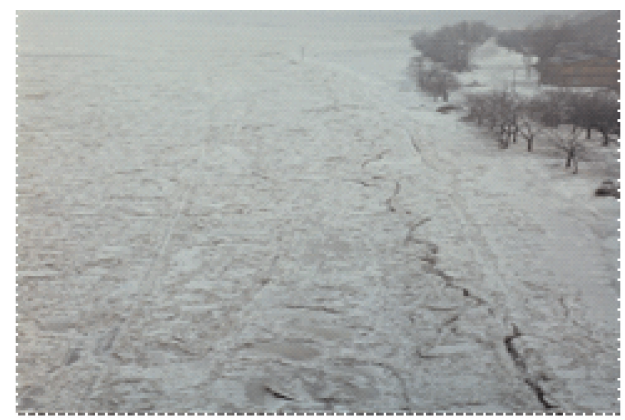

Ice cover on the Vistula. Visible crack along the border due to decreased discharge

Fig. 17. Ice cover on the Vistula (cross-section Płock) formed of compressed ice pans

\section{Influence of Ice Cover on Velocity Distribution and Flow Resistance}

Ice cover over the whole width of river may be often accompanied by hanging dams (deposits of frazil ice or other ice forms. Sometimes these deposits may take the whole flow depth from ice cover to the bottom (Fig. 18).

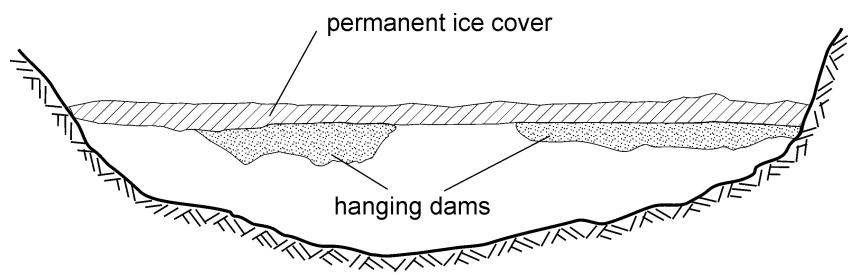

River cross-section with solid ice cover and hanging dams (deposits)

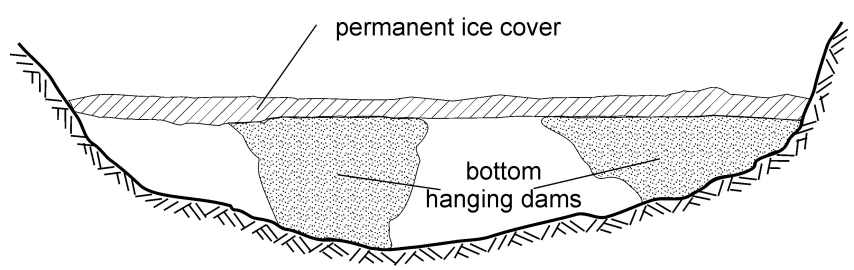

River cross-section with solid ice cover and ice deposits extending even to the river bottom

Fig. 18. River cross-sections with various ice forms

Various forms of ice cover and other ice forms can distinctly reflect in the velocity distribution (Fig. 19), which in turn may change location and forms of ice. This process may take longer time. 


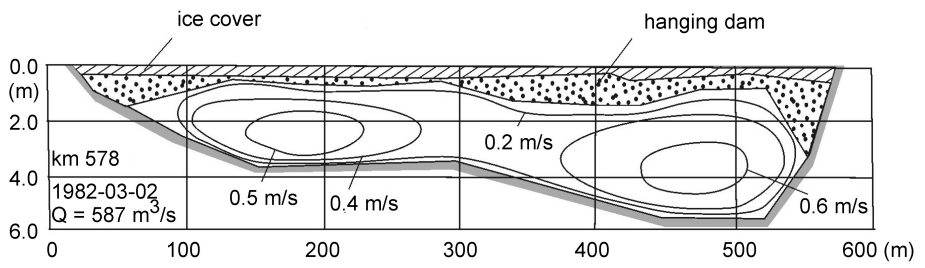

Velocity distribution in river cross-section

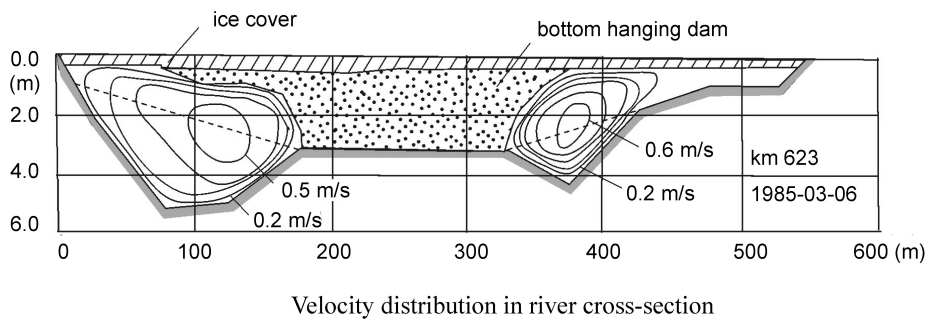

Fig. 19. Velocity distribution in river cross-sections with various ice forms

\section{Flow Velocity in Rivers with Ice Cover}

Fig. 20 shows river cross-section with ice cover over the whole width of the channel. The cross-section can be divided into two parts (dashed line). The upper part $\left(A_{I}\right)$ is under the influence of ice cover and the bottom one under the influence of the channel bottom. Ice cover is characterized by ice thickness $(I)$ and its roughness of the underside defined by the Darcy-Weisbach roughness factor $\left(f_{I}\right)$ or Manning roughness coefficient $\left(n_{I}\right)$. In case of wide river channels wetted perimeters of ice and river bottom are nearly equal. River cross-section with ice cover is characterized by equivalent hydraulic radius $\left(R_{0}\right)$ significantly different from hydraulic radius $(R)$ for free surface flow.

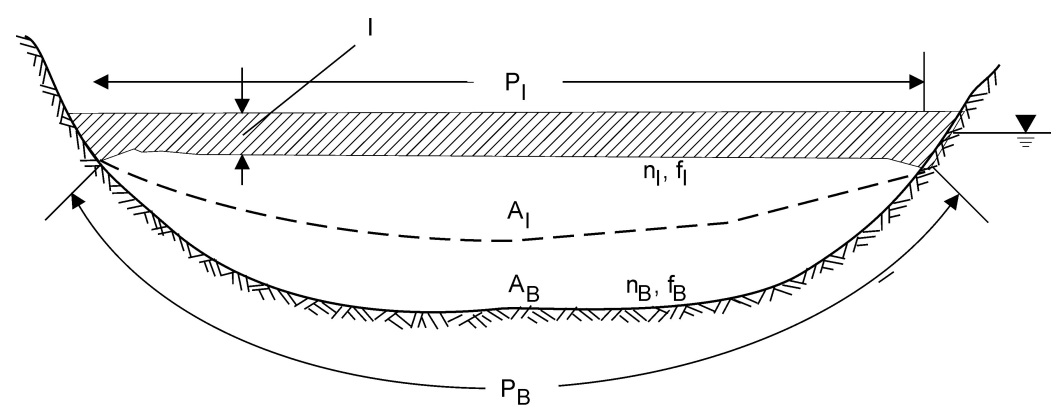

Fig. 20. Schematic river cross-section with ice cover

Total wetted perimeter $P_{0}=P_{I}+P_{B}$ and total flow area $A_{0}=A_{I}+A_{B}$ and thus equivalent hydraulic radius $R_{0}=A_{0} / P_{0}$. It is clear that equivalent (composite) hydraulic radius $R_{0}$ will be nearly twice smaller then hydraulic radius for free surface 
flow and thus flow velocity and consequently discharge for river with ice cover will be smaller than for free surface flow.

Velocity distribution in the river flow with ice cover is significantly different from velocity, which exists in free surface flow. Two examples of measured velocity distribution in the Vistula river are shown in Fig. 19. Schematic flow distribution in the vertical is shown in Fig. 21.

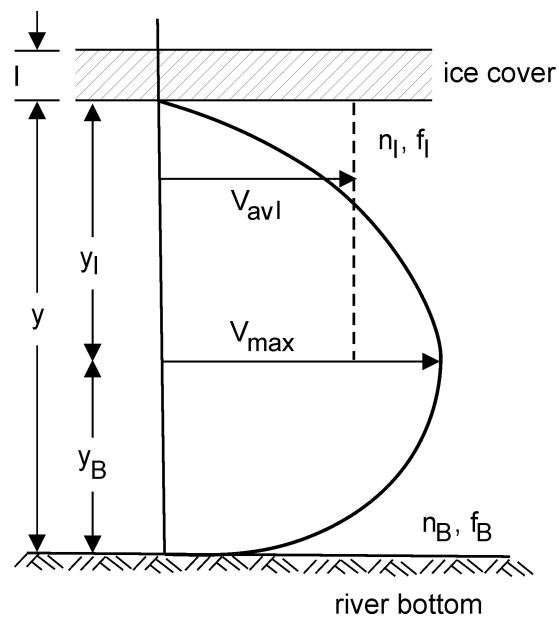

Fig. 21. Schematic velocity distribution in the river flow with ice cover

\section{Roughness of the Underside of Ice Cover}

This velocity distribution is mainly governed by the roughness of the underside of ice cover and the roughness of river bottom (Calkins et al 1980, Majewski 2003). The position of maximum velocity is somewhere between river bottom and ice cover. Its location depends on the values of roughness of these two boundaries. If the value of roughness of these both surfaces is equal then maximum velocity will be in the middle of the flow depth. If these roughness have different values then maximum velocity will move towards surface of the smaller roughness, which exhibits smaller flow resistance. We can distinguish average flow velocities in the ice and bottom region (Tatinclaux and Gogus 1983). The distribution of hydrostatic pressures, shear stresses and velocity distribution is shown in Fig. 22.

Ice which has lower density then water is floating on water surface. The hydrostatic pressure $\left(P_{I}\right)$ on the underside of ice cover amounts to $P_{I}=\rho_{I} \cdot g \cdot I$. Shear stresses on the bottom and underside of ice cover have appropriate values $\tau_{B}$ and $\tau_{I}$ and the value zero at the point of maximum velocity.

There are many proposals to describe velocity distribution over the solid surface of different roughness. One of them is logarithmic distribution, which is based on 


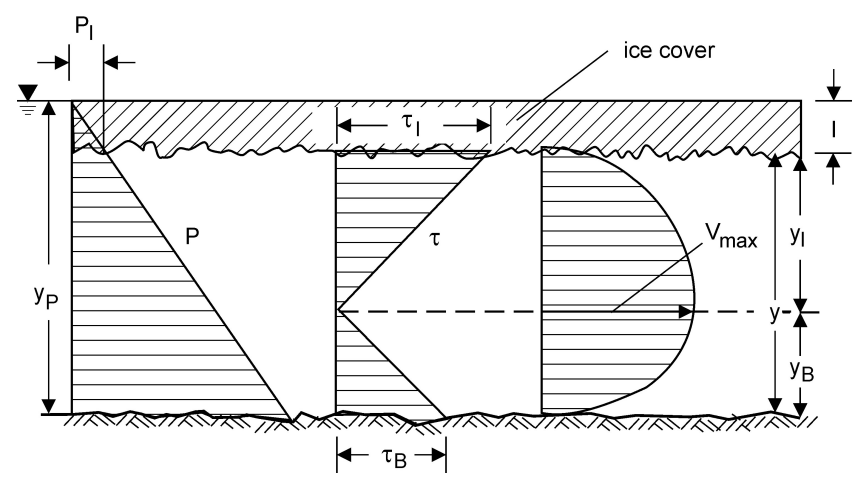

Fig. 22. Distribution of hydrostatic pressures, shear stresses, and velocity in the flow with ice cover

Prandtl-Karman velocity distribution in turbulent flow. It can be presented in the form of Eq. 11

$$
v=\frac{1}{\kappa} v * \ln \frac{y}{y_{0}}
$$

where:

$$
\begin{aligned}
& \kappa-\text { Karman constant }(0.4), \\
& v *-\text { dynamic velocity }(g R S)^{1 / 2}, \\
& y_{0}-\text { integration constant }(\mathrm{m}), \\
& y-\text { flow depth }(\mathrm{m}),
\end{aligned}
$$

For rough surfaces this formula assumes the form

$$
v=\frac{1}{\kappa} v_{*} \ln \frac{30 y}{k}
$$

where: $k$ - linear dimension of the roughness.

This formula can be presented in a linear form (Eq. 13)

$$
v=a \ln y+b .
$$

Fig. 23 presents results of in situ measurements of velocity distribution under ice cover (with frazil deposit)

These results are presented in the graphical form (Fig. 24)

Fig. 24 shows the calculated velocity data in the linear form. Very good coincidence of measured and calculated velocity distribution was obtained (correlation coefficient 0.989 ). The equation of velocity distribution has the form

$$
v=0.137 \ln y+0.5 \text {. }
$$

From Eq. 13 it is possible to define the location of the curve of velocity distribution with the vertical line

$$
y_{0}=\exp \left(-\frac{b}{a}\right)
$$




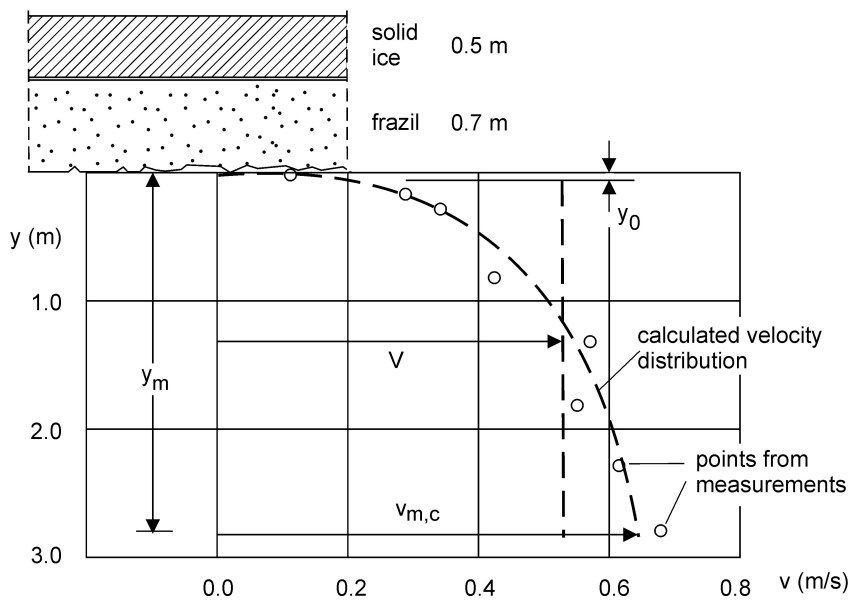

Fig. 23. Velocity distribution in the flow under ice cover

Table 2. Measured data of velocity distribution

\begin{tabular}{|c|c|c|}
\hline$y(\mathrm{~m})$ & $v(\mathrm{~m} / \mathrm{s})$ & $\ln y$ \\
\hline 0.05 & 0.11 & -3.00 \\
\hline 0.20 & 0.29 & -1.61 \\
\hline 0.30 & 0.34 & -1.20 \\
\hline 0.85 & 0.43 & -0.16 \\
\hline 1.35 & 0.58 & 0.30 \\
\hline 1.85 & 0.56 & 0.62 \\
\hline 2.30 & 0.62 & 0.83 \\
\hline 2.85 & 0.67 & 1.05 \\
\hline
\end{tabular}

Integrating the logarithmic velocity distribution (Eq. 12) over the depth from $y_{0}$ to $y_{\max }$ it is possible to determine the average velocity over this depth

$$
V=\frac{v_{\max } \cdot y_{\max }}{y_{\max }-y_{0}}-a .
$$

The inconvenience of logarithmic velocity distribution is the fact that for $v_{\max }$ the tangent to the curve of velocity is not vertical. Assumption of the velocity distribution as logarithmic gives, however, the possibility to calculate Darcy-Weisbach friction factor $\left(f_{I}\right)$ for the underside of ice cover or Manning roughness coefficient $\left(n_{I}\right)$.

$$
\begin{gathered}
f_{I}=1.28\left(\frac{v_{m}}{V}-1\right)^{2}, \\
n_{I}=\sqrt{\frac{f_{I}}{8 g}}\left(y_{m}-y_{o}\right)^{1 / 6} .
\end{gathered}
$$




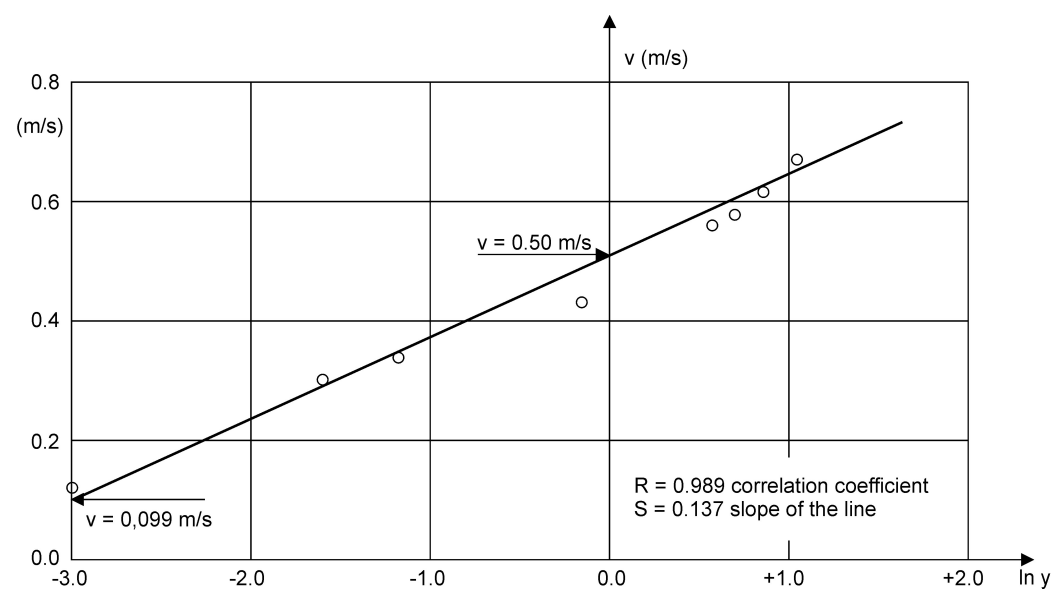

Fig. 24. Results of calculations of the correlation of velocity distribution under ice cover

For the data presented in Fig. 23 we obtained calculated values $V=0.51 \mathrm{~m} / \mathrm{s}$, $v_{\max }=0.64 \mathrm{~m} / \mathrm{s}$, and $y_{0}=0.03 \mathrm{~m}$. Applying Eq. 17 we obtain $f_{I}=0.0832$ and applying Eq. 18 we obtain $n_{I}=0.038$. It shows that calculation of $f_{I}$ and $n_{I}$ on the basis of logarithmic velocity distribution under ice cover gives reliable results. However, values obtained for a given vertical may be different than for other verticals in the same cross-section and must be regarded as approximate.

Measurements of the location of maximum velocity under ice cover from the moment of its formation show that it changes during the existence of ice cover. It depends what means that underside of ice cover becomes more smooth with time thus resulting in smaller roughness. This may be result of melting or increasing the thickness of ice cover on its underside surface.

\section{Composite (Resultant) Roughness Coefficient}

Calculation of the average velocity in a cross-section with ice cover requires to take into account river bed roughness but also the thickness of ice cover and its underside roughness. Very often in 1D flow we describe composite roughness (resultant) by means of composite Manning roughness coefficient, because calculations of average flow velocity in the river cross-section we carry out mainly using Manning formula (Uzuner 1975). This formula is valid for steady, uniform turbulent flow. There were numerous studies devoted to solve this problem. They were based on the assumption of division of the whole cross-section area in two parts. The upper, which is under the influence of ice cover and the bottom one, which is under the influence of river bottom. The most popular formula for calculation of composite roughness is the Sabaniejew formula (Larsen 1969)

$$
n_{0}=\left(\frac{n_{I}^{3 / 2}+n_{B}^{3 / 2}}{2}\right)^{2 / 3}
$$


This formula is based on the assumption that $P_{I} \approx P_{B}$ (wide river channel). Manning roughness coefficients for the underside of ice cover are usually in the range from 0.010 to 0.080 although values higher than 0.080 are also encountered. Manning roughness coefficients for the river bottom are usually in the range $0.020-0.040$. These values may differ in consecutive verticals of the cross-section and in $1 \mathrm{D}$ calculations we must assume average values. Calculations of flow velocity or river conveyance along river section is usually carried out from cross-section to cross-section for which all necessary data are required.

The value of the roughness coefficient of the underside of ice cover has a very important influence on flow velocities. In energy channels we are interested to achieve the highest velocities for a given flow depth. Often applied practice is to stop the operation of hydraulic power plant and allow to form static ice cover on the energy channel with smooth underside ice cover. The start of the operation of hydraulic power plant is after ice cover formation, which takes one or two days. Static ice cover has usually smooth underside ice cover.

\section{Calculation of Steady Uniform Flow with Continuous Ice Cover}

The majority of river hydraulic situations can be defined as steady uniform flow with ice cover. They can be considered as a quasi pressure flow with floating ice cover. It is characterized with parallel energy line, water surface and the bottom. Water surface line is about $1 / 10$ of ice thickness below floating ice surface. Such assumptions allow us to apply in our calculations the formula of Manning or Chezy. We are interested to obtain the value of discharge for a given flow depth with ice cover (thickness, roughness of the underside), in a defined channel (slope, cross-section, bottom roughness coefficient), or what depth in the channel will be for a given discharge. In case of determining water discharge for the flow with ice cover calculation is rather simple and defined with formula (18)

$$
Q_{0}=A_{0} \cdot V_{0}=A_{0} \frac{1}{n_{0}} R_{0}^{2 / 3} S^{1 / 2}
$$

where:

$$
\begin{aligned}
& A_{0}-\text { flow cross-section under ice cover }\left(\mathrm{m}^{2}\right), \\
& V_{0}-\text { average flow velocity }(\mathrm{m} / \mathrm{s}), \\
& n_{0}-\text { composite Manning roughness coefficient, } \\
& R_{0}-\text { hydraulic radius }(\mathrm{m}) \\
& S-\text { slope of energy line. }
\end{aligned}
$$

Flow cross-section under ice cover is defined from the formula

$$
A_{0}=A-0.92 I \cdot B
$$

where: 


$$
\begin{aligned}
& I-\text { ice thickness }(\mathrm{m}), \\
& B-\text { width of the cross-section }(\mathrm{m}), \\
& A-\text { cross-section for free surface flow }\left(\mathrm{m}^{2}\right) .
\end{aligned}
$$

Ice density is lower then water, and therefore we have floating ice cover and water level will be nearly $10 \%$ lower of ice thickness counting from the upper surface of ice cover.

Example 1. For a given water level in river cross-section with ice cover determine the value of discharge. Ice thickness $I=0.10 \mathrm{~m}$, roughness of the underside of ice cover $n_{I}=0.040$, bottom roughness $n_{B}=0.030$, width of the river channel $B=80 \mathrm{~m}$, ice wetted perimeter $P_{I}=80 \mathrm{~m}$, Bottom wetted perimeter $P_{B}=95 \mathrm{~m}$, flow area for given free surface water level $A=128 \mathrm{~m}^{2}$, slope of the river channel $S=00035$. Flow area $A_{0}$ for this cross-section we calculate from Eq. $21, A_{0}=128-0.92 \cdot 0.10 \cdot 80=$ $120.6 \mathrm{~m}^{2}$. Wetted perimeter for the cross-section with ice cover is $P_{0}=P_{I}+P_{B}=$ $95+80=175 \mathrm{~m}$, hydraulic radius for the cross-section $R_{0}=A_{0} / P_{0}=120.6 / 175=$ $0.70 \mathrm{~m}$. Composite roughness coefficient calculated from the Eq. $19, n_{0}=0.035$. Applying Eq. 20 we can calculate discharge in the cross-section, $Q_{0}=50.8 \mathrm{~m}^{3} / \mathrm{s}$.

For comparison the value of discharge in this cross-section without ice cover $Q=97.5 \mathrm{~m}^{3} / \mathrm{s}$. This means that the appearance of ice cover resulted in significant decrease of discharge by nearly $50 \%$. This means that for a given free surface discharge water level with the presence of ice cover will be much higher. Therefore people must understand and be prepared that when ice cover will appear on the river, water level for the same discharge will be much higher then for free surface flow. Such calculation is more complicated then in previous case, and will require trial and error method (Example 2).

Example 2. For a given river cross-section, given discharge and ice cover calculate the resultant water level. Necessary data: discharge $\left(\mathrm{m}^{3} / \mathrm{s}\right)$, river cross-section in numerical form, river slope, ice thickness $(\mathrm{m})$, roughness coefficient of the underside of ice cover (Manning coefficient), roughens of the river bed (Manning coefficient). We assume (first trial) water level and consecutively calculate. Flow cross-section $A\left(\mathrm{~m}^{2}\right)$, wetted perimeter for ice cover $P_{I}(\mathrm{~m})$, bottom wetted perimeter $(\mathrm{m})$, flow cross-section under ice cover $A_{0}\left(\mathrm{~m}^{2}\right)$, hydraulic radius for the cross-section with ice cover $R_{0}$, composite roughness coefficient $n_{0}$ and finally discharge ( $\left.\mathrm{m}^{3} / \mathrm{s}\right)$ (Eq. 20). If the calculated discharge is equal to the assumed discharge the calculation is terminated. If not, we assume next water level and calculate discharge till the moment when calculated discharge is equal to the initially assumed discharge.

\section{Flow in Rivers with Partial Ice Cover}

Very often we have situation in which not the whole width of river cross-section is covered with ice cover. This may happen when border ice forms or when icebreakers 
make an ice free channel in continuous ice cover. This is an often applied practice to decrease water level in river channel fully covered with ice cover. The measurements indicate that flow velocities in the ice-free part of the channel are much higher then in the ice covered part of the channel. The scheme of river cross-section for such case is shown in Fig. 25. Here cross-section has 3 parts. Two parts are near the river shore with ice cover and in the middle we have the third part which has free surface flow. It is assumed that the slope of energy line is the same for all three parts. In each part we determine the following values.

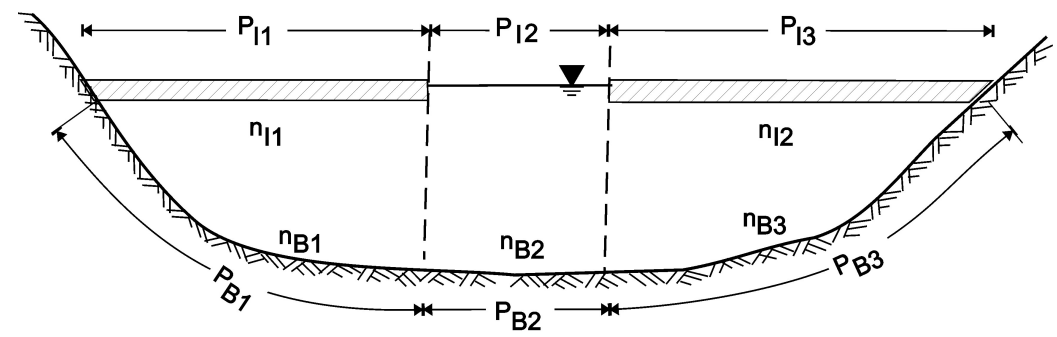

Fig. 25. Schematic flow cross-section with partial ice cover

- Wetted perimeter $\left(P_{B}\right)$ and roughness coefficient $\left(n_{B}\right)$ for the bottom.

- Wetted perimeter of the underside of ice cover $\left(P_{I}\right)$.

- Total wetted perimeter $\left(P_{0}\right)$.

- Flow cross-section under ice cover $\left(A_{0}\right)$.

- Hydraulic radius $\left(R_{0}\right)$.

- Composite roughness coefficient $\left(n_{0}\right)$.

- Conveyance of the flow $K$ (Eq. 22)

- Total flow in the cross-section $Q$ (Eq. 23).

Conveyance for each part of the cross-section we calculate from Eq. 22

$$
K=\frac{A_{0} R_{0}^{2 / 3}}{n_{0}} .
$$

Total discharge through the cross-section is calculated from Eq. 23

$$
Q=\left(\sum_{l=1}^{j} K_{i}\right) S^{1 / 2} .
$$

Example 3. For the cross-section shown in Fig. 25 (3 parts) calculate discharge for the partial ice cover, continuous ice cover and for the cross-section without ice cover. The data for the calculation are as follows.

- Slope of the energy line $S=0.0004$,

- Thickness of ice cover $I=0.15 \mathrm{~m}$, 
- Width of ice free channel $25 \mathrm{~m}$.

All remaining initial and calculated data connected with this problem are included in Table 3.

Table 3. Initial and calculated data for Example 3

\begin{tabular}{|c|c|c|c|c|c|c|c|c|}
\hline $\begin{array}{c}\text { Part } \\
\text { No }\end{array}$ & $\begin{array}{c}A_{0} \\
\left(\mathrm{~m}^{2}\right)\end{array}$ & $\begin{array}{c}P_{I} \\
(\mathrm{~m})\end{array}$ & $\begin{array}{c}P_{B} \\
(\mathrm{~m})\end{array}$ & $n_{I}$ & $n_{B}$ & $n_{0}$ & $\begin{array}{c}R_{0} \\
(\mathrm{~m})\end{array}$ & $K$ \\
\hline \hline 1 & 88 & 48 & 53 & 0.032 & 0.030 & 0.031 & 0.87 & 2587 \\
\hline 2 & 70 & $(25)$ & 25 & - & 0.030 & 0.030 & 2.80 & 4635 \\
\hline 3 & 91 & 53 & 58 & 0.035 & 0.030 & 0.032 & 0.82 & 2491 \\
\hline \hline$\Sigma$ & 249 & 126 & 136 & & & & & 9713 \\
\hline
\end{tabular}

For cross-section with ice-free channel calculated discharge is

$$
Q=\Sigma K S^{1 / 2}=9713 \cdot 0.0004^{1 / 2}=194 \mathrm{~m}^{3} / \mathrm{s} .
$$

It is possible to calculate flow velocities in every part of the cross-section using Eq. 24

$$
V=K \frac{S^{1 / 2}}{A_{0}}
$$

This way we obtain the following average velocities in consecutive parts of the cross-section

$$
V_{1}=0.59 \mathrm{~m} / \mathrm{s}, \quad \mathrm{V}_{2}=1.32 \mathrm{~m} / \mathrm{s}, \quad \mathrm{V}_{3}=0.55 \mathrm{~m} / \mathrm{s} .
$$

Calculation of discharge through the cross-section assuming that whole cross-section is covered with ice. Initial and calculated values are presented in Table 4.

Table 4.

\begin{tabular}{|c|c|c|c|c|c|c|c|c|}
\hline $\begin{array}{c}A_{0} \\
\left(\mathrm{~m}^{2}\right)\end{array}$ & $\begin{array}{c}P_{B} \\
(\mathrm{~m})\end{array}$ & $\begin{array}{c}P_{I} \\
(\mathrm{~m})\end{array}$ & $\begin{array}{c}R_{0} \\
(\mathrm{~m})\end{array}$ & $n_{B}$ & $n_{I}$ & $n_{0}$ & $\begin{array}{c}V_{0} \\
(\mathrm{~m} / \mathrm{s})\end{array}$ & $\begin{array}{c}Q \\
\left(\mathrm{~m}^{2} / \mathrm{s}\right)\end{array}$ \\
\hline \hline 245 & 136 & 127 & 0.93 & 0.030 & 0.033 & 0.032 & 0.60 & 147 \\
\hline
\end{tabular}

The value of calculated discharge when the whole cross-section is covered with ice with $0.15 \mathrm{~m}$ thickness is $147 \mathrm{~m}^{3} / \mathrm{s}$. For comparison the velocity $(V)$ and the discharge $(Q)$ through this cross-section without ice cover will be using Manning formula

$$
V=1.03 \mathrm{~m} / \mathrm{s} \text { and } \mathrm{Q}=271 \mathrm{~m}^{3} / \mathrm{s} \text {. }
$$

\section{Ice Jam Flood on Włocławek Reservoir in 1982}

The Vistula section which includes the present reservoir was always very ice prone and numerous ice jams occurred here resulting in floods. It was quite obvious that 
construction of the barrage Włocławek and about $50 \mathrm{~km}$ long run-of-river reservoir will considerably change hydraulic, thermal and ice regime of this river section (Biegała 1983). Hydraulic model investigations, which were carried out during design stage, included the passage of ice floes through the spillways and stilling basin of the barrage, which showed their correct operation. Calculations of back-water profile along the reservoir with continuous ice cover were carried out for discharges which are usually present in the Vistula during autumn and spring time in order to determine how water levels will increase due to the presence of ice cover. In these calculations the roughness coefficient of the underside of ice cover on the reservoir was assumed as $0.030-0.040$ and also various thicknesses of ice cover.

The change of hydraulic conditions resulted in the decrease of flow velocities. Significant changes were near to the weir where the depth increased to about $15 \mathrm{~m}$. In the upper part of the reservoir hydraulic conditions were very similar to the river flow. As the consequence of hydraulic conditions important changes were observed in ice regime. Nearly every winter there was stable ice cover over the whole reservoir. During free surface flow the formation of frazil ice and its passage was about 48 days during year. After the formation of the reservoir this ice passage was shortened to 8 days in favor of continuous ice cover formation. The time of stable ice cover duration increased from 28 to 64 days. Before flood in 1982 there were several changes of water levels in the cross-section Płock ( $\mathrm{km}$ 632.5) observed due to local ice jams. They were untypical and not related to discharge (Fig. 26).

Water levels along the final section of the reservoir are very strongly influenced by the Vistula River upstream. This natural braided river, not fully trained, was very often producer of large quantities of ice floes and frazil ice. At the same time the reservoir was already covered with solid ice cover. Frazil ice which flows into the reservoir formed hanging dams and very often frazil deposits which completely block part of the flow cross-section. This resulted in increased water levels which can exceed warning levels and sometimes even alarm stages. Two of such situations are presented in Fig. 26.

It is very interesting that along the Lover Vistula we can have one, two and even sometimes three ice periods during one winter. By the ice period we understand the sequence of ice cover situations. When due to low air temperatures stable ice cover forms, it may happen that later comes period of higher air temperatures and rain, resulting in increased discharge, which causes break-up and ice-run. When after some days air temperatures drop down and new ice cover forms, which usually consists of compressed ice floes and frazil ice. It usually has large thickness and very rough underside. This formation of ice cover we call juxtaposition. This is next ice period.

Exceptional and very dangerous ice-jam situation appeared during winter 1981/ 1982 (Kaczmarek 1982). In December 1981 there was period of law air temperatures with, thick ice cover and large amounts of snow. At the end of December 1981 and in the beginning of January 1982 air temperature increased considerably with simultaneous ice-breakup and ice-run over the whole Lower section of the Vistula. 

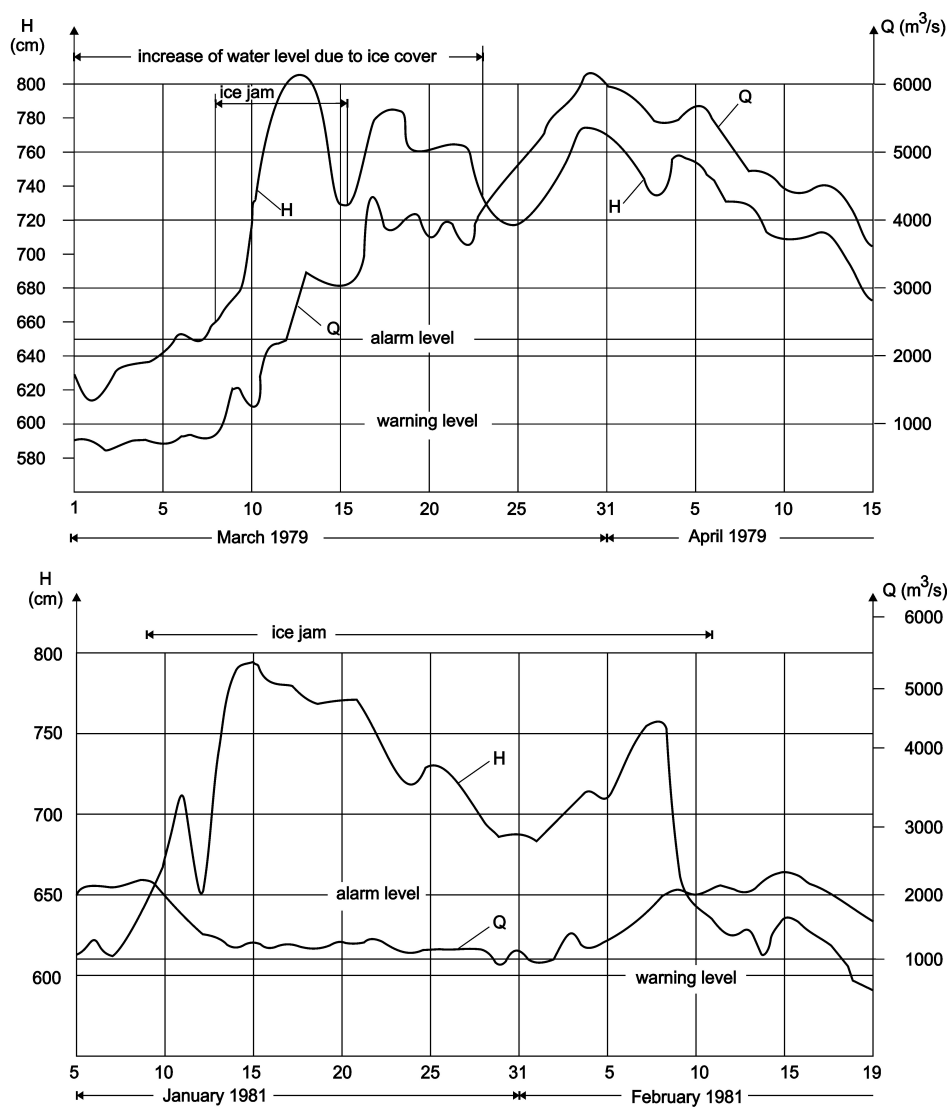

Fig. 26. Two situations of the relation discharge - water level for cross-section Płock due to ice jam

This situation is shown in Fig. 27. Suddenly on the 6th January considerable drop of air temperature appeared (about $20^{\circ} \mathrm{C}$ ) together with strong wind blowing against the flow in the reservoir. This stopped the movement of ice floes downstream (through the spillways of the barrage Włocławek) and immediately formed by juxtaposition very rough ice cover. Large amounts of frazil ice formed at the Vistula section upstream from the reservoir. These large amounts of frazil ice met solid ice cover on the reservoir and moved into reservoir under the solid ice cover forming hanging dams and thus decreasing flow cross-section. Simultaneous increase of discharge to the value about $3500 \mathrm{~m}^{3} / \mathrm{s}$ resulted in the increase of water level by nearly $3 \mathrm{~m}$ (Fig. 27).

High water stages resulted in breaching left hand side dams in 5 places from $\mathrm{km}$ 648 to 620 and about $18 \mathrm{~km}^{2}$ of the terrain were flooded resulting in high economic and social losses. The first breach of side dam was on the January 8 at 12.00 and the last on the January 10 at 13.00. It is interesting that the breaches of side dams began in $\mathrm{km} 648$ and moved upstream during two consecutive days. Numerous farms were flooded and 14 thousand people were evacuated with 11 thousand of farm animals. 


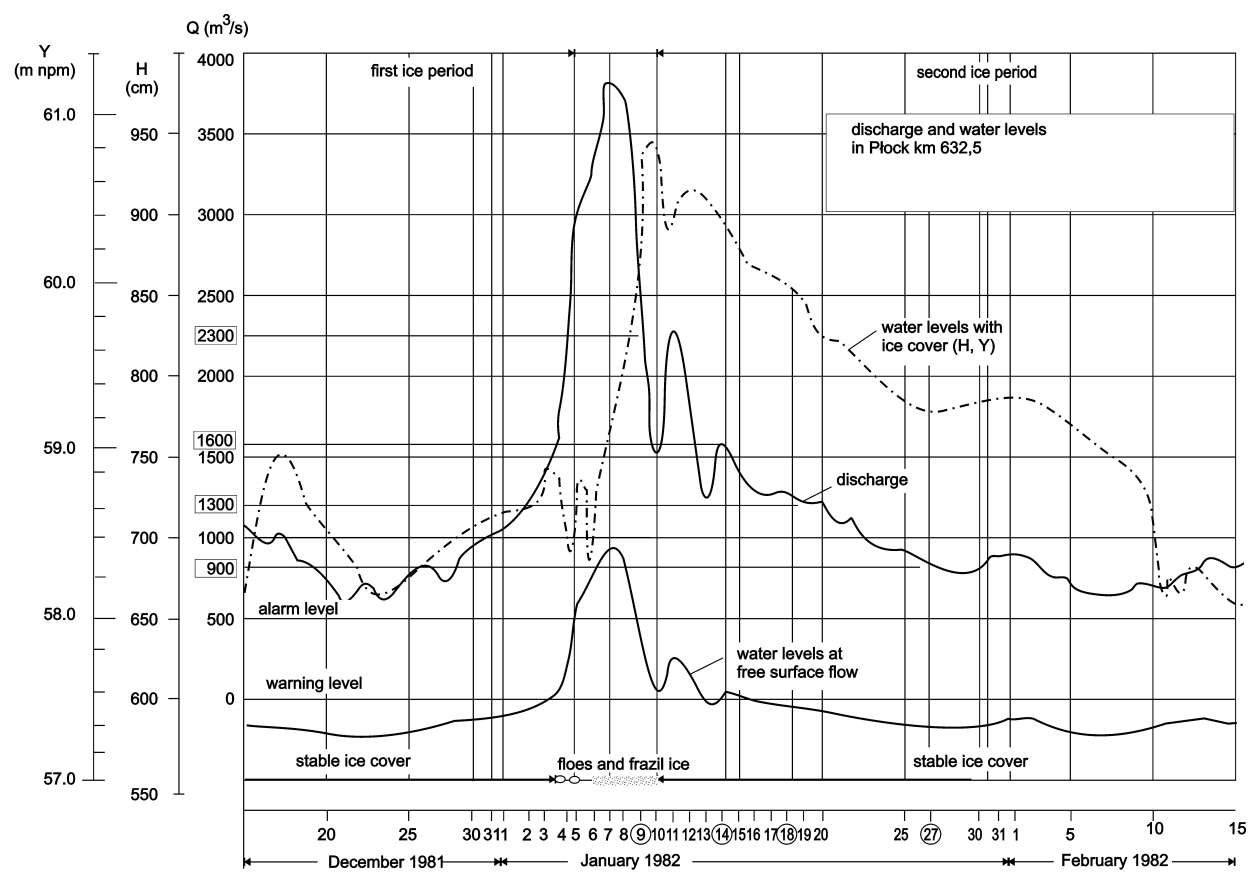

Fig. 27. Hydraulic situation in the cross-section Płock Dec. 1981 - Jan. 1982

Oil pipeline crossing the the river on a suspended bridge at $\mathrm{km} 630$ was very seriously endangered due to very high increase of water level and ice at the end of the reservoir (3 $\mathrm{m}$ above normal water level). The situation of flooded area is presented in Fig. 28.

After this flood there were many questions: why this flood occurred and what was its main reason. There were arguments that the main reason of the flood was the existence of Włocławek barrage and its reservoir. This question had to be answered because there were very high social and economic losses. The answer to this question is that ice jam and subsequent flood occurred due to coincidence of very unfavorable hydro-meteorological conditions and some negligence in the upper part of the reservoir.

Extensive field measurements were carried out after ice-jam flood on the Włocławek reservoir. They included the data about ice cover on the whole reservoir in 29 cross-sections ( $\mathrm{km} 675$ to 632.5), water stages, which were measured and controlled at the barrage together with actual discharges, as well as water elevations along the whole reservoir. Discharge during measurements was changing in the range from 900 to $3800 \mathrm{~m}^{3} / \mathrm{s}$. In some cross-sections with ice cover, velocity distribution was measured in several verticals thus giving velocity distribution in the whole flow cross-section. Examples of these measurements are shown in Fig. 19.

Mathematical model of backwater profile was developed for the the whole reservoir based on existing profiles. It was 1D steady, uniform flow model with calculations of water levels in consecutive cross-sections. It was possible to carry out calculations 


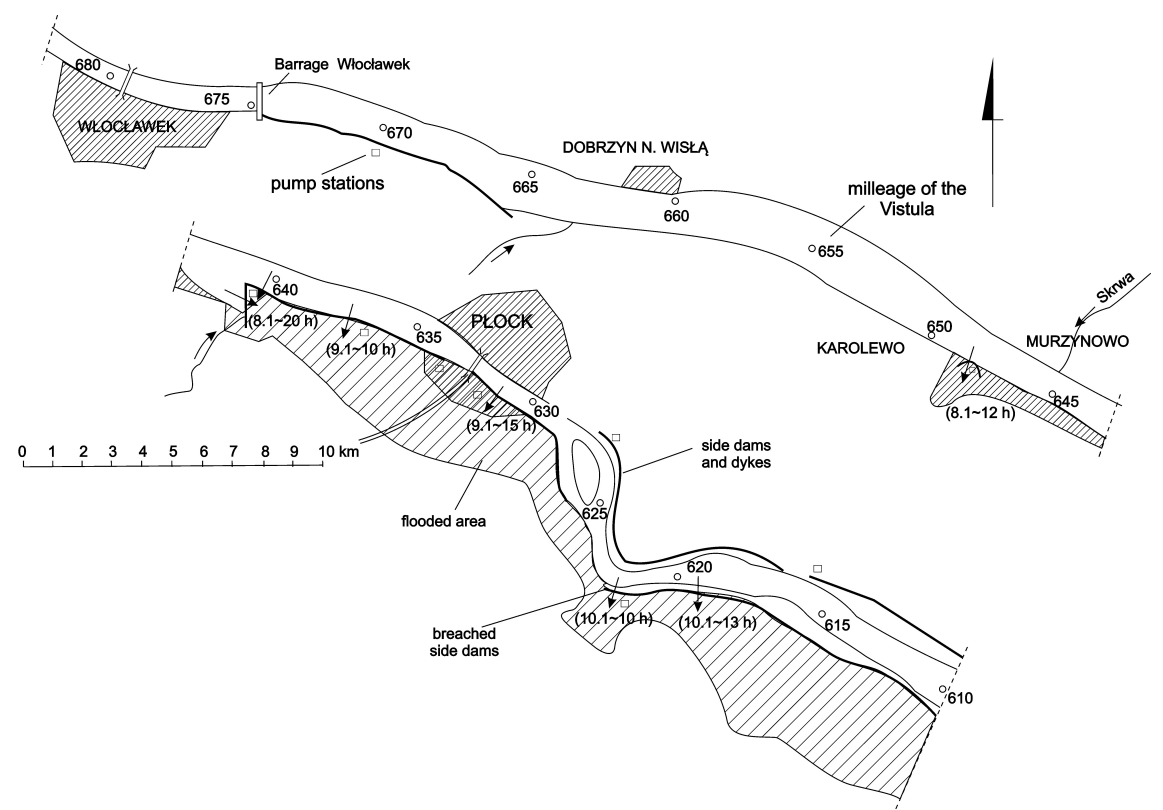

Fig. 28. Flooded areas on the left hand side of Włocławek reservoir

for various water discharge and ice thickness. The model was developed for continuous ice cover, but also for partial ice cover (ice free channel). It was 1D model and therefore all data had to be averaged in consecutive cross-sections. One of the main problems was the value of the roughness of the underside of ice cover, (Manning roughness coefficient), which appeared as a very important factor. The main idea for this study was the calculation of water levels along the reservoir, starting at the barrage cross-section to the final cross-section $(\mathrm{km} \mathrm{32.5).} \mathrm{Calculations} \mathrm{were} \mathrm{performed} \mathrm{from}$ initial cross-section (barrage) to next cross-sections going in the upstream direction.

Calculation of the position of energy line $(H)$ and its slope $(S)$ in cross-section 1 (barrage) is performed by two formulas (Eq. 25). For initial cross-section (1) the following values are necessary: discharge $\left(\mathrm{m}^{3} / \mathrm{s}\right)$, ice thickness $(\mathrm{m})$, Manning roughens coefficient for the river bottom and underside of ice cover and initial water level $Y(\mathrm{~m})$

$$
H=Y+\frac{V_{0}}{2 g}, \quad S=\frac{V_{0}^{2} n_{0}^{2}}{R_{0}^{4 / 3}}
$$

where:

$Y \quad-\quad$ water level in initial cross-section (m),

$V_{0}^{2} / 2 g-$ increase of depth due to water energy (m),

$S \quad-$ slope of energy line,

$n_{0} \quad-$ composite Manning roughness coefficient,

$R_{0} \quad-\quad$ hydraulic radius, which includes river bottom and ice cover (m). 
In the next cross-section (2) we assume water level $\left(Y_{2}\right)$ and calculate (Fig. 26) position of energy line $H_{2}$ (first formula), the slope of energy line $\left(S_{2}\right)$, as well as $H_{2}^{\prime}$, where $\Delta X$ is the distance between cross-sections (m). By means of trial and error procedure we correct the value of $Y_{2}$ till the moment when $H_{2}-H_{2}^{\prime}<0.002 \mathrm{~m}$.

$$
H_{2}=Y_{2}+\frac{V_{2}^{2}}{2 g}, \quad S=\frac{V_{0}^{2} n_{0}^{2}}{R_{0}^{4 / 3}}, \quad H_{2}^{\prime}=H_{1}+\Delta X \frac{S_{1}+S_{2}}{2} .
$$

Performed calculations for various discharges, ice thicknesses and continuous or partial ice cover in the whole cross-section indicate, which parameter is the most important for water levels in the final cross-section. It appeared that this is roughness coefficient of the underside of ice cover. To achieve the values of water levels which were during ice-jam flood in the region of Płock, Manning roughness coefficients of the underside of ice cover should reach very high values of $n_{I}$ even 0.150 . Results of such calculations are shown in Figs. 29, 30 and 31.

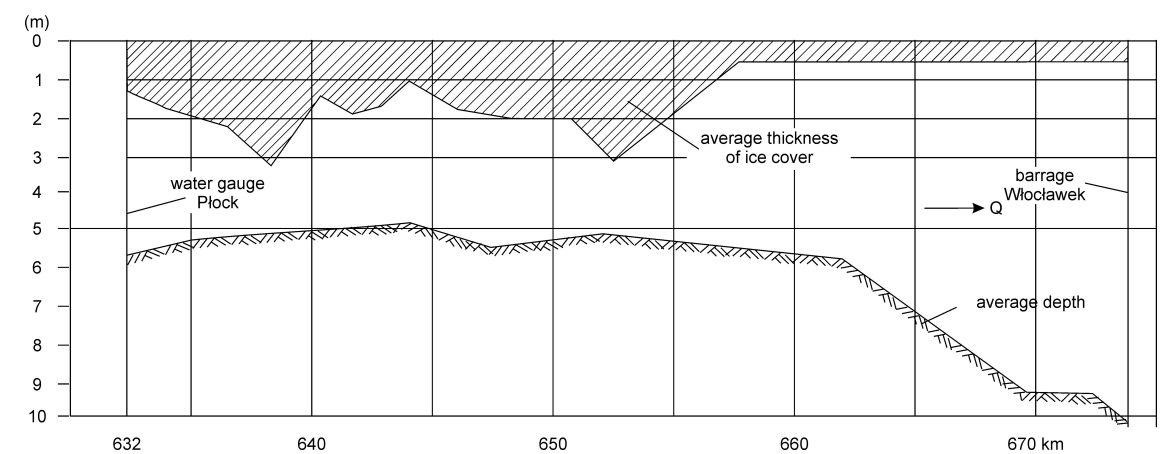

Fig. 29. Average depths and ice thickneses on the Włocławek Reservoir during flood 1982

\section{Engineering Actions on the Barrage Włocławek and Reservoir after Flood 1982}

After the flood all breached side dams were repaired and where necessary their height was increased. The oil pipeline location was changed as under the river bed construction in order to avoid future danger of its breaching by increased level of ice cover. In front of the gates on the weir a special aeration system was installed. Perforated pipes were located at the bottom and compressed air was connected to these pipes. The movement of air bubbles prevented the adhesion of ice cover to the steel gates thus enabling their operation during very low temperatures.

Important action was the removal of all bushes, which appeared in the upper part of the reservoir as well as dredging of this part. This had to prevent any stoppage of frazil ice or ice floes and thus formation if any ice-jam in the future. 


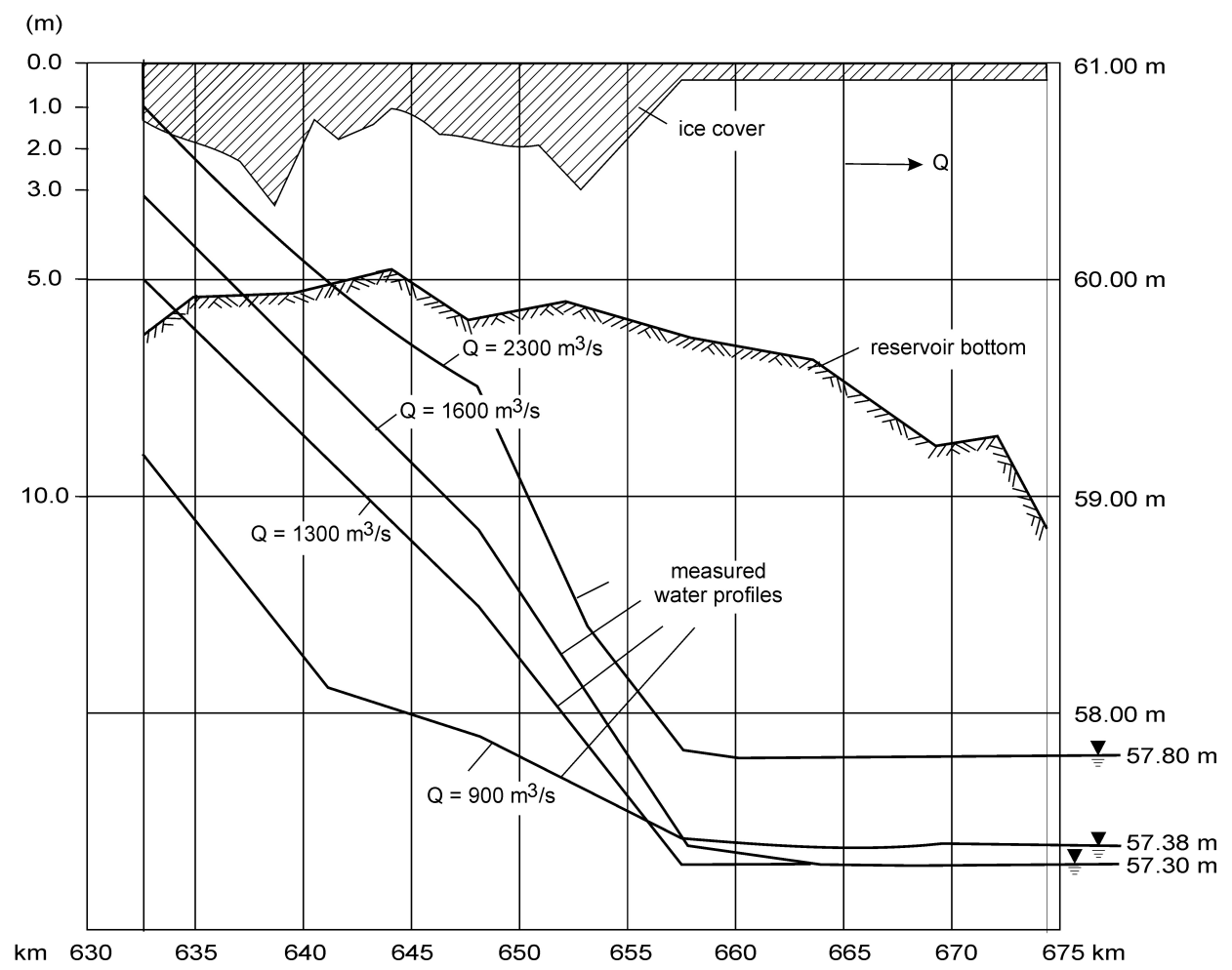

Fig. 30. Measured backwater profiles on the Włocławek Reservoir in January 1982

The main problem, however, which caused ice jam was the inflow of frazil ice and ice floes to the reservoir from the Vistula upstream of the reservoir. To solve this problem special floating ice booms in $\mathrm{km} 630$ were installed (Polak 1987). They consisted of 4 bays and stretched over the whole width of water surface. They were anchored to the river bottom. They operated correctly till flow velocities of about 0.6 $\mathrm{m} / \mathrm{s}$. With higher velocities the floating ice fragments dive below ice boom and flow into the reservoir. Ice booms have double aim. First is the stoppage of frazil ice and ice floes against entering into the reservoir and the second fast formation of ice cover on the river upstream. Such ice cover forms the insulation of water surface against the loss of heat to the atmosphere and thus prevents the formation of frazil ice.

One of the main problems during ice-jam flood in 1982 on the Włocławek Reservoir was the operation of ice-breakers (Wrycza 1998). It was a standard procedure that formation of ice-free channel in the ice cover on the reservoir results in significant lowering of water level. This is the result of much higher discharge in the part of the reservoir with free surface. Important, however, condition is the possibility of the outflow of ice floes and ice fragments along this ice-free channel. Sometimes there are difficulties to form such channel when ice thickness is large and has some hanging dams under ice cover. Proper power capacity of icebreakers is necessary as well as 


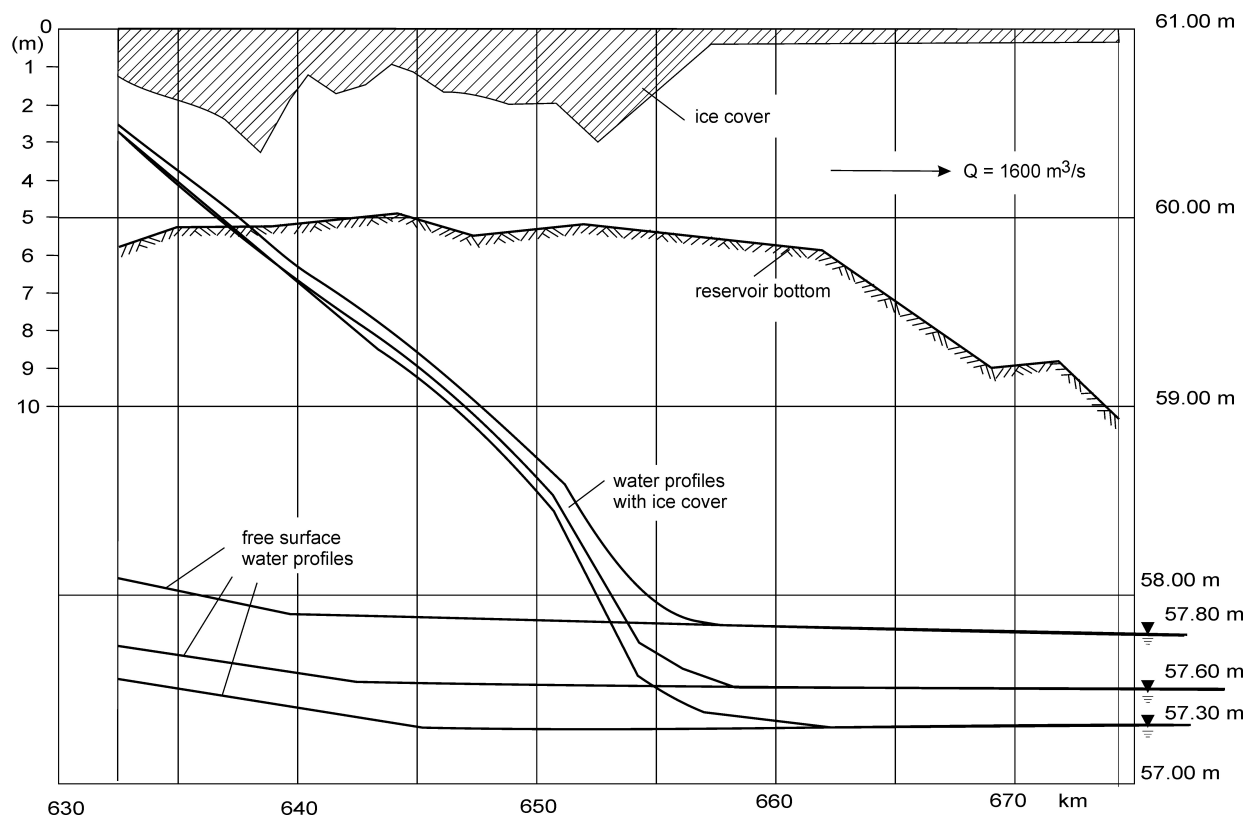

Fig. 31. Calculated backwater profiles on the Włocławek Reservoir for various initial water levels on the barrage Włocławek

proper amount of such units. It is always well known that any ice breaking must begin in lower part of the reservoir going in the upstream direction.

\section{Conclusions}

In many countries of the northern hemisphere in autumn and in winter due to decreased air temperatures thermal regime of inland waters changes considerably and initiates the possibilities of the formation of various ice forms. There is a variety of ice forms depending very much, whether they form on stagnant or flowing water.

These ice forms cause important changes in hydraulic regime but also in winter thermal regime. These conditions depend very much on the area where they appear. In Poland two main rivers Oder and Vistula flow from their source in the south to their outlet to the sea in the north. Very often when in the south there is ice break-up and ice-run in the north inland waters are still frozen. In many situations this resulted in ice jams and ice-jam floods.

The Lower Vistula (390 km long river section) was always very ice prone resulting in ice-jam floods, which brought considerable social, economic and also environmental losses. Forecasts of such situations is very difficult, because they depend on numerous hydrologic, hydraulic and thermal conditions. One of the most important information is the areal distribution and character of ice cover. In wide rivers the continuous ice cover follows the discharge and breaks along the shore, thus forming a quasi pressure flow underneath. This flow considerably differs from the free surface 
flow, because of increased wetted perimeter and thus decreased value of hydraulic radius.

Calculations of hydraulic characteristics of ice covered channels are complicated by the fact that very often we do know what is the thickness of ice cover, but more important that we do not know what is the roughness of the underside of ice cover. This can change in a very wide range not only spatially but also temporally.

It is quite clear that appearance of any ice form on inland waters results in additional problems of the water use for navigation, hydroenergy, thermal energy or water supply. There are additional possibilities to eliminate or at least mitigate the influence of ice forms on water utilization. These are ice breakers or ice booms. Their application is, however, sometimes limited.

In many situations the appearance of any ice form and especially continuous ice cover will result in increased water depth in comparison with free surface flow. One of very often practiced, from engineering point of view, forms to decrease water level with ice cover is the formation by icebreakers an ice-free channel (Fig. 32). Efficiency of this solution depends on the conditions of the outflow of crushed ice cover downstream. It is evident that crushing of ice cover by ice-breakers must begin in the downstream cross-section and proceed in the upstream direction.

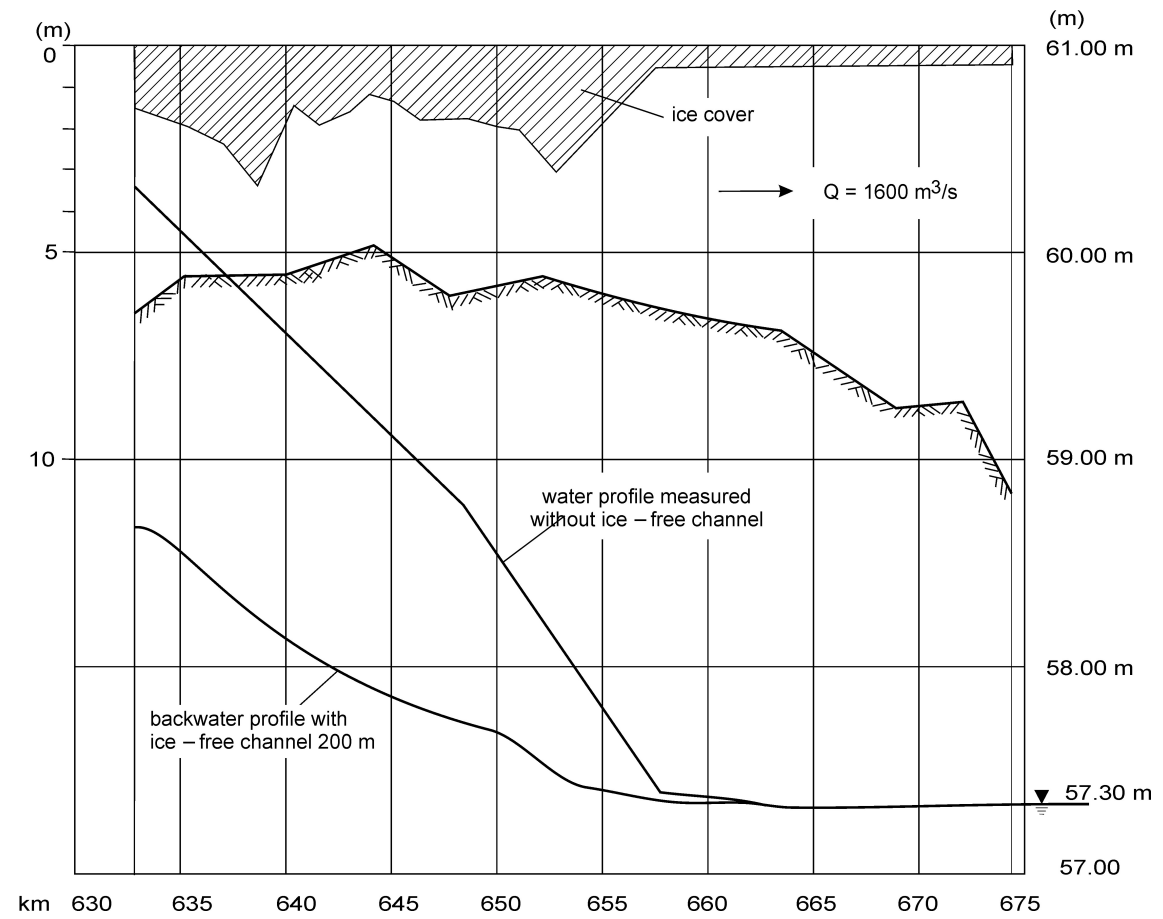

Fig. 32. Measured backwater profile on the Włocławek Reservoir for continuous ice cover and calculated backwater profile with ice free channel of the widths $200 \mathrm{~m}$ 
Ice regime situation on the Lower Vistula and in particular ice-jam flood on the upper part of Włocławek Reservoir in 1982 show clearly how complicated case it was. To find solution and exact causes of this flood required numerous field measurements and theoretical studies. It is very clear that this flood was mainly caused by the appearance of very unfavorable hydro-meteorological conditions on the Lower Vistula and not the existence of the barrage and reservoir. Construction of the next barrage downstream is indispensable for the proper operation and safety of barrage and reservoir Włocławek. At present there are many numerical models, which allow to calculate the possibilities of ice cover formation and its influence on hydraulic regime of the river section or run-of-river reservoir (Spyros-Editor 2013).

\section{References}

Ashton G. D. (1986) River and Lake Ice Engineering, Water Resources Publications, USA.

Biegała L. (1983) The Role of Barrage Wtoctawek in Ice-jam Flood in January 1982, Water Management No. 5.

Calkins D. J. et al (1980) Analysis of Velocity Profiles Under Ice in Shallow Streams, Proceedings of workshop on hydraulic resistance of river ice, Center of Inland Waters, Burlington, Canada.

Chow V. T. (1959) Open channels hydraulics, Mc Graw-Hill Book Company, N.York, Toronto, London.

Dobrowolski A. B. (1923) Natural History of Ice, Warsaw (in Polish).

Gerard R. (1980) Flow in Ice Covered Channels: Some Fundamentals, Proceedings of workshop on hydraulic resistance of river ice, Canada Center for Inland Waters Ice Engineering, Engineering and Design (1982), US Corps of Engineers, Washington.

Gołek J. (1957) Ice Phenomena on Polish Rivers, PIHM, Warsaw (in Polish).

Griszanin K. W. (1969) Dynamics of River Flow, Hydrometeorological Publication, Leningrad (in Russian).

Grześ M. (1991) Ice Jams and Ice-Jam Floods on the Lover Vistula, Mechanisms and Conditions, Institute of Geography and Spatial Management PAS, Warsaw (in Polish).

Hammar L., Shen H. T., Evers K. U., Kolerski T., Yuan Y., Sobczak Ł. (2002) A Laboratory Study on Freezeup Ice Runs in River Channels, 16th International Symposium on Ice IAHR, Dunedin.

Henderson F. M. (1966) Open Channel Flow, Macmillan New York, London.

Kaczmarek Z. (1982) Report of National Commission for the Investigation of Causes and Consequences of the Flood in January 1982 on the Vistula and other Rivers, Warsaw (in Polish).

Kolerski T. (2004) Unsteady Flow with Ice Cover in Open Channels and Run-of-River Reservoirs, Doctors Thesis, Institute of Hydroengineering PAS in Gdańsk (in Polish).

Kolerski T. (2016) Mathematical Modelling of Ice phenomena on Inland Waterways, Publication of Gdańsk University of Technology (in Polish).

Lambor J. (1948) Genesis of Frazil Ice, PIHM Warsaw (in Polish).

Lambor J. (1959) Ice Phenomena on Polish Waterways, Warsaw (in Polish).

Lambor J. (1971) Hydrology, ARKADY, Warsaw (in Polish).

Larsen P. (1969) Head losses Caused by Ice Cover on Open Channels, Journal of the Boston Society of Civil Engineers, January. Lower Vistula Cascade, 1993, PROEKO, Warsaw.

Majewski W. (1985) Thermal Regime of Rivers and Reservoirs in Winter Conditions, Guidebook of Hydroengineerig Designer, 4-5/1985 (in Polish).

Majewski W. (Editor) et al (1985) Ice-Jam Flood on the Vistula in the region of Wtoctawek Reservoir in 1982, Geological Publication, Warsaw (in Polish). 
Majewski W. (1986) Ice problems at Hydropower Installations and Hydraulic Structures, Proceedings IAHR Ice Symposium, Iowa City, USA.

Majewski W. (1987) Influence of Ice Cover on the Hydraulic Characteristics of Run-off-River Reservoirs on Lowland Rivers, Case Study of Wtoctawek Reservoir, Institute of Hydroengineering PAS in Gdańsk (in Polish).

Majewski W. (2003) Determination of roughness coefficient of the underside of ice cover, Archives of Hydro-engineering and Environmental Mechanics, 50 (3), 219-228.

Majewski W. (2007) Flow in Open Channels Under the Influence of Ice Cover, Acta Geophysica, 55 (1).

Majewski W. (2009) Open Channel Flow under the Influence of Ice Phenomena, IMGW Warsaw (in Polish).

Majewski W. (2015) Direct Channel of the Vistula and its Consequence for Flood Protection of Żuławy, Scientific-Technical Conference, Gdansk (in Polish).

Ozga-Zielińska M., Brzeziński Z. (1994) Applied Hydrology, PWN, (in Polish).

Paily P. P. et al (1974) Winter Regime and Thermal Response of Heated Streams, Journal of Hydraulics Division, April.

Pasławski Z. (1970) Influence of Ice Phenomena on River Flow, PIHM, Warsaw (in Polish), Vol. 99, Warszawa.

Polak K. (1987) Frazil Ice Boom on the Vistula in km. 629,9, Guidebook of the Hydroengineering Designer No 3.

Shen H. T. (1991) River Ice Processes and Hydraulics, Clarkson University, Potstam, USA.

Spyros B. (Editor) (2013) River Ice Formation, Committee on River Ice Processes and the Environment Canada, Edmonton.

Tatinclaux J. C., Gogus M. (1983) Asymmetric Plane Flow with Application to Ice Jams, Journal of Hydraulic Engineering ASCE, 109 (11).

Tsang G. (1982) Frazil and Anchor Ice, A Monograph, NRC Subcommittee on Hydraulics of Ice Covered Rivers, Ottawa, Canada.

Uzuner M. S. (1975) The Composite Roughness of Ice Covered Streams, Journal of Hydraulic Research, 13 (1).

Wrycza T. (1998) Icebreaking, Publication Monolit, Gdynia (in Polish). 